\title{
Development of a source oriented version of the WRF/Chem model and its application to the California regional $\mathbf{P M}_{10} / \mathbf{P M}_{2.5}$ air quality study
}

\author{
H. Zhang ${ }^{1}$, S. P. DeNero ${ }^{1}$, D. K. Joe ${ }^{1}$, H.-H. Lee ${ }^{2}$, S.-H. Chen ${ }^{2}$, J. Michalakes ${ }^{3}$, and M. J. Kleeman ${ }^{1}$ \\ ${ }^{1}$ Department of Civil and Environmental Engineering, University of California, Davis, One Shields Avenue, Davis, CA, USA \\ ${ }^{2}$ Department of Land, Air, and Water Resources, University of California, Davis, One Shields Avenue, Davis, CA, USA \\ ${ }^{3}$ National Renewable Energy Laboratory, Golden, CO, USA
}

Correspondence to: M. J. Kleeman (mjkleeman@ucdavis.edu)

Received: 8 May 2013 - Published in Atmos. Chem. Phys. Discuss.: 19 June 2013

Revised: 16 November 2013 - Accepted: 2 December 2013 - Published: 15 January 2014

\begin{abstract}
A source-oriented version of the Weather Research and Forecasting model with chemistry (SOWC, hereinafter) was developed. SOWC separately tracks primary particles with different hygroscopic properties rather than instantaneously combining them into an internal mixture. This approach avoids artificially mixing light absorbing black + brown carbon particles with materials such as sulfate that would encourage the formation of additional coatings. Source-oriented particles undergo coagulation and gasparticle conversion, but these processes are considered in a dynamic framework that realistically "ages" primary particles over hours and days in the atmosphere. SOWC more realistically predicts radiative feedbacks from anthropogenic aerosols compared to models that make internal mixing or other artificial mixing assumptions.

A three-week stagnation episode (15 December 2000 to 6 January 2001) in the San Joaquin Valley (SJV) during the California Regional $\mathrm{PM}_{10} / \mathrm{PM}_{2.5}$ Air Quality Study (CRPAQS) was chosen for the initial application of the new modeling system. Primary particles emitted from diesel engines, wood smoke, high-sulfur fuel combustion, food cooking, and other anthropogenic sources were tracked separately throughout the simulation as they aged in the atmosphere.

Differences were identified between predictions from the source oriented vs. the internally mixed representation of particles with meteorological feedbacks in WRF/Chem for a number of meteorological parameters: aerosol extinction coefficients, downward shortwave flux, planetary boundary layer depth, and primary and secondary particulate matter
\end{abstract}

concentrations. Comparisons with observations show that SOWC predicts particle scattering coefficients more accurately than the internally mixed model. Downward shortwave radiation predicted by SOWC is enhanced by $\sim 1 \%$ at ground level chiefly because diesel engine particles in the source-oriented mixture are not artificially coated with material that increases their absorption efficiency. The extinction coefficient predicted by SOWC is reduced by an average of $0.012 \mathrm{~km}^{-1}(4.8 \%)$ in the SJV with a maximum reduction of $\sim 0.2 \mathrm{~km}^{-1}$. Planetary boundary layer (PBL) height is increased by an average of $5.2 \mathrm{~m}(1.5 \%)$ with a maximum of $\sim 100 \mathrm{~m}$ in the SJV. Particulate matter concentrations predicted by SOWC are $2.23 \mu \mathrm{g} \mathrm{m}^{-3}(3.8 \%)$ lower than the average by the internally mixed version of the same model in the SJV because increased solar radiation at the ground increases atmospheric mixing.

The changes in predicted meteorological parameters and particle concentrations identified in the current study stem from the mixing state of black carbon. The source-oriented model representation with realistic aging processes predicts that hydrophobic diesel engine particles remain largely uncoated over the +7 day simulation period, while the internal mixture model representation predicts significant accumulation of secondary nitrate and water on diesel engine particles. Similar results will likely be found in any air pollution stagnation episode that is characterized by significant particulate nitrate production. Future work should consider episodes where coatings are predominantly sulfate and/or secondary organic aerosol. 


\section{Introduction}

The Weather Research and Forecast (WRF) model developed primarily by the National Center for Atmospheric Research (NCAR) and the National Oceanic and Atmospheric Administration (NOAA) is frequently used to predict meteorological conditions during stagnation events that lead to high concentrations of air pollutants (Borge et al., 2008; Hu et al., 2010; Huang et al., 2010; Zhang et al., 2012). The WRF model with chemistry (WRF/Chem) allows for coupled simulations of atmospheric chemistry and meteorology so that feedbacks can be considered (Chapman et al., 2009; Fast et al., 2006; Grell et al., 2005; Peckham et al., 2011). These feedback effects can be especially important during air pollution episodes that occur as a result of stagnation events, which are characterized by weak synoptic forcing of winds, leading to the buildup of pollutant concentrations close to emissions sources. Atmospheric mixing is largely determined by the distribution of incoming radiation throughout the vertical column in stagnation events. Airborne particles in the air pollution mixture scatter and/or absorb solar radiation, which alters the vertical distribution of solar energy, atmospheric mixing, and therefore dilution rates (Chapman et al., 2009; Liao et al., 2009).

The size, composition, and mixing state of airborne particles strongly affect their optical properties and their effects on solar radiation (Jacobson, 2001; Mogo et al., 2012). Current versions of $\mathrm{WRF} / \mathrm{Chem}$ have state-of-the-science representations of particle size and composition (Ackermann et al., 1998; Ginoux et al., 2001; Zaveri et al., 2008), but relatively simple representations of particle mixing state. WRF/Chem makes a global internal mixing assumption in which all particles with the same size in the same grid cell are instantaneously combined such that they have the same chemical composition. In reality, airborne particles become internally mixed over a period of hours to days depending on atmospheric conditions (Riemer et al., 2004, 2010). The instantaneous internal mixing assumption alters the optical properties of particles in WRF/Chem simulations and therefore has the potential to bias air pollution-meteorology feedback calculations in the WRF/Chem model.

More sophisticated treatments of airborne particle mixing state have been used in 1-D box models (Zaveri et al., 2010) or 2-D trajectory models (Kleeman and Cass, 1998) but these frameworks cannot support a full simulation of meteorological feedbacks on a regional scale. Regional 3$\mathrm{D}$ air quality models that represent particle mixing state as a source-oriented external mixture have been available for more than a decade (Held et al., 2004; Kleeman, 2001; Ying et al., 2007). These models have tracked source contributions to primary and secondary particulate matter from 8 700 sources (Hu et al., 2013; Ying et al., 2008a; Zhang et al., 2013; Zhang and Ying, 2010, 2011) but they have not attempted to calculate feedbacks to meteorology other than modification of photolysis rates (Ying and Kleeman, 2003).
Basic assumptions about particle mixing state beyond the internal mixture approximation have been included in proprietary coupled meteorology-air pollution models (Jacobson, 2001; Vogel et al., 2009). Matsui et al. (2013) recently proposed a 3-D model that can simulate realistic black carbon mixing states if condensation and coagulation process are calculated explicitly. These calculations have emphasized the role of black carbon as a potential short-lived climate forcing agent, but verification of these results by the broader scientific community has not been possible due to the lack of a publically available tool capable of such calculations.

The purpose of the current paper is to demonstrate how a full source-oriented representation of airborne particles would influence predicted air pollution concentrations in the publicly available WRF/Chem model. A source-oriented aerosol model represents particles emitted from different sources using separate chemical composition so that it is possible to simulate multiple particles with the same size but different chemical composition in the same grid cell. Atmospheric processes such as coagulation and gas-particle conversion age particles over time, but these processes occur over hours to days.

In this work, the structure of the source-oriented WRF/Chem (SOWC) model is described, and the application of the model to a severe air pollution episode in central California is discussed. Source-oriented particles in 8 size bins are resolved for diesel engines, wood smoke, high-sulfur combustion, food cooking, and other anthropogenic sources. The current study calculates from first principles the composition and mixing state of each particle source type and size bin across the domain while considering all relevant atmospheric processes including feedbacks to meteorology. Differences between model predictions for the vertical distribution of energy, momentum, and pollutant concentrations carried out with internal vs. source-oriented external representations of airborne particles are quantified, and recommendations are made for future research directions.

\section{Background}

Numerous air quality studies have used the source-oriented representation of particles to understand how different sources contribute to air pollution (Chen et al., 2009; Kleeman, 2001; Mahmud et al., 2010; Ying and Kleeman, 2003, 2006; Zhang and Ying, 2012). Kleeman et al. (1997) showed that representing a plume as an externally mixed aerosol led to specific differences in composition between particles of the same diameter. Their study showed that an externally mixed representation will separate out species such as $\mathrm{Na}^{+}$and $\mathrm{SO}_{4}^{2-}$ that exist independently in the real world environment, while an internally mixed plume will combine these into one aerosol. It was also observed through their results that with increasing relative humidity, the external mixture model could accurately predict a mono-disperse 


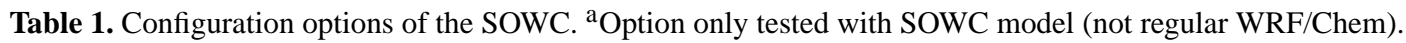

\begin{tabular}{|c|c|c|c|}
\hline \multicolumn{2}{|c|}{ WRF options } & \multirow{2}{*}{$\begin{array}{l}\text { Used in this study } \\
\text { Source-oriented representation }^{\mathrm{a}}\end{array}$} & \multirow{2}{*}{$\begin{array}{l}\text { References } \\
\text { Kleeman (2001), Ying et al. (2007) }\end{array}$} \\
\hline Registry & $\begin{array}{l}\text { Particle } \\
\text { representation }\end{array}$ & & \\
\hline \multirow[t]{9}{*}{ Physics } & Microphysics & Lin et al. scheme & Lin et al. (1983) \\
\hline & Longwave radiation & $\begin{array}{l}\text { A comparable GSFC longwave radiation } \\
\text { module }^{\mathrm{a}}\end{array}$ & $\begin{array}{l}\text { Chou and Suarez (1999), } \\
\text { Chou et al. (2001), Chen et al. (2010) }\end{array}$ \\
\hline & Shortwave radiation & Goddard shortwave & Chou and Suarez (1994) \\
\hline & Land surface & Noah land surface model & Mitchell et al. (2003) \\
\hline & Planetary boundary layer & Yonsei University scheme & Hong et al. (2006) \\
\hline & $\begin{array}{l}\text { Cumulus } \\
\text { parameterization }\end{array}$ & Kain-Fritsch scheme & Kain (2004) \\
\hline & Urban surface & Urban canopy model & Masson (2000) \\
\hline & Diffusion & $\begin{array}{l}\text { Simple diffusion with ACM2 in vertical } \\
\text { direction }^{\mathrm{a}}\end{array}$ & Pleim (2007) \\
\hline & Advection & $\begin{array}{l}\text { Positive definite advection of scalars, moisture, } \\
\text { and chemistry variables (3rd order) }\end{array}$ & $\begin{array}{l}\text { Tremback et al. (1987) } \\
\text { Only works with EM_CORE }\end{array}$ \\
\hline \multirow[t]{8}{*}{ Chemistry } & $\begin{array}{l}\text { Gas phase } \\
\text { mechanism }\end{array}$ & SAPRC90 & Carter (1990) \\
\hline & Photolysis & $\mathrm{UCD} / \mathrm{CIT}^{\mathrm{a}}$ & Kleeman (2001) \\
\hline & Dry deposition gas & Wesely & Wesely (1989) \\
\hline & Dry deposition PM & $\mathrm{UCD} / \mathrm{CIT}^{\mathrm{a}}$ & Kleeman (2001) \\
\hline & Wet deposition & Not enabled & \\
\hline & Coagulation & A source-oriented coagulation ${ }^{\mathrm{a}}$ & $\begin{array}{l}\text { Ying et al. (2008a), } \\
\text { Zhang and Ying (2010) }\end{array}$ \\
\hline & Aerosol partitioning & $\begin{array}{l}\text { APDC and ISORROPIA }{ }^{\mathrm{a}} \\
\text { SOA partitioning not enabled }\end{array}$ & Jacobson (2005), Nenes et al. (1998) \\
\hline & Nucleation & Not enabled & \\
\hline
\end{tabular}

aerosol evolving into a bimodally distributed aerosol. Ying et al. (2009) studied source contributions to secondary pollutants formation within California's Central Valley using a source-oriented air quality model. They identified diesel engines as the largest contributor to particle nitrate and agricultural sources as the leading source of the secondary ammonium ion.

Black carbon has been identified as a major contributor to global warming (Jacobson, 1998) but the assumptions about the mixing state of black carbon (what chemical components exist in the same particles with black carbon) have a large impact on the calculation (Lesins et al., 2002; Mallet et al., 2004). Very few studies have incorporated externally mixed particles into simulations that involve radiative feedbacks, and the majority of the studies that have considered this complication have made simplifying assumptions about the mixing state of the black carbon contained in those particles. For example, Jacobson (1998) studied the effects of sourceresolved aerosols on photolysis and temperatures within and above urban areas, and found that aerosols increased radiative heating within the air column, but decreased solar flux at the surface. The study assumed that when particles contained more than $5 \%$ secondary organic material and UV (ultraviolet) wavelengths were considered, the shell was comprised of secondary organics while the rest of each particle was core material. When particles contained less than $5 \%$ secondary organics and visible wavelengths were considered, the core was assumed to be elemental (black) carbon. These a priori assumptions influence the calculated optical properties of particles. The goal of the present study is to explicitly calculate the mixing state of particles without a priori assumptions.

\section{Model description}

The source oriented WRF/Chem (SOWC) model was created using the framework of the Weather Research and Forecasting model coupled with chemistry (WRF/Chem) version 3.1.1. The changes necessary to add source-oriented aerosols to the WRF/Chem model fall within three branches of the code: the registry, the chemistry driver, and the Eulerian mass-conservation dynamic core (EM_CORE). Table 1 lists the configuration options and new features with their applicability of the SOWC. The model was configured with the Lin et al. microphysics scheme (Lin et al., 1983) and the KainFritsch cumulus parameterization scheme (Kain, 2004). The Noah land surface model (Mitchell et al., 2004) and urban canopy model (Masson, 2000) are used for land surface and 
urban surface. The details of the modification are provided in the Supplement with the main features summarized below.

\subsection{Representation of particles and gas-phase species}

Particles in each Eulerian grid cell of the SOWC model are described by their size bin (a moving bin approach), sourceorigin, number concentration, and chemical composition using 6 dimension arrays $(i, k, j$, source, size, species). The chemical species of particles included in this study are listed in Table A1 of the Supplement. Eight size bins are considered in this study and their size ranges are shown in Table A2 of the Supplement. Number concentration and radius were included as the last two elements in the species dimension in order to simplify the coding structure. The model conserves number concentrations and mass concentration throughout the simulation of atmospheric processes including emissions, transport, deposition, coagulation, and condensation/evaporation. Particle radius is updated after each major operator step to reflect the actions of operators that differentially affect number and mass concentrations. Figure $2 \mathrm{~b}$ illustrates a representative snapshot of source-oriented particles in the current study. The gas-phase species in each grid cell are not source-oriented in the current study. Future work will extend the source-oriented treatment to gas-phase species in support of source apportionment calculations for secondary particulate matter (Ying and Kleeman, 2009; Ying et al., 2009), but these calculations have no impact on the radiative feedback between air pollution and meteorology that forms the focus of the current study.

\subsection{Emissions, initial and boundary conditions}

Source-oriented emissions were created based on emission inventories for the California Regional $\mathrm{PM}_{10} / \mathrm{PM}_{2.5}$ Air Quality Study (CRPAQS) period supplied by the California Air Resources Board (CARB) (Ying et al., 2008a). The regulatory inventories were transformed into source, size, and chemistry-resolved modeling inventories using emission profiles measured during detailed source tests (Kleeman et al., 2008; Robert et al., 2007a, b). Natural sources of aerosols were described using a combination of offline and online techniques. Dust emissions were directly included in the offline inventory from CARB. Sea salt was included using an online emissions subroutine that is based on correlations between emissions and surface wind speed.

Concentrations measured during the CRPAQS winter field campaign were used as initial and boundary conditions as discussed in previous modeling studies (Ying et al., 2008a, b, 2009). In the present study, the interpolated concentrations on the western (upwind) edge of the modeling domain were averaged as a best estimate of initial aerosol concentrations for all the vertical layers. The same concentrations were specified along all four boundaries in the current study. Both initial conditions and boundary conditions were lumped into the unresolved "other" sources category of the sourceoriented framework.

\subsection{Gas-particle partitioning in ISORROPIA and coagulation}

The SAPRC90 (Statewide Air Pollution Research Center) gas phase mechanism (Carter, 1990) was implemented in the SOWC model using the SAPRC mechanism compiler maintained by the University of California at Davis (UCD). The gas-phase reaction system was solved using standard operators to calculate photolysis rates, update the temperature dependent rate constants, and integrate the chemical reaction system. The extinction of UV radiation by sourceoriented particles was accounted for in the calculated photolysis rates. The SAPRC90 mechanism was selected to enable a comparison to previous modeling studies using an offline air quality model (Ying et al., 2008a). The mechanism compiler makes it simple to update the gas-phase chemistry to later versions of the SAPRC mechanism. The addition of the SAPRC mechanism followed the standard treatment used by the UCD family of air quality models, which allows for future enhancements to track sources of secondary aerosol and the incorporation of new SOA mechanisms.

Gas-particle interaction is a complex process that consumes a sizeable fraction of the total chemistry-related computing time in the SOWC model. The SOWC model uses the analytical predictor for dissolution and condensation (APDC) approach outlined by Jacobson (2005) for gasparticle conversion of inorganic species (J. J. Chen et al., 2010). In this approach, the ammonium ion is held in equilibrium while the anion concentrations are solved dynamically. Mass and charge balance equations are then used to determine final concentrations of each component. This numerical solution is stable at larger time steps (150-300 s), which greatly reduces the computational burden of gas-particle conversion. The vapor pressures of inorganic gases $\mathrm{HNO}_{3}, \mathrm{HCl}$, $\mathrm{H}_{2} \mathrm{SO}_{4}$, and $\mathrm{NH}_{3}$ immediately above the particle surface are calculated using the ISORROPIA equilibrium solver. These concentrations are updated for every particle source and size bin at each model time step. A list of the equilibrium relations and constants used in the aerosol model is shown in Table A3 of the Supplement. Aerosol water content is calculated based on the particle composition of each particle using the ZSR (Zdanovskii-Stokes-Robinson) method (Stokes and Robinson, 1966). The current study resolves the distribution of aerosol water among source-oriented aerosols, which may result in modified optical properties (Beaver et al., 2010) when there is a difference in chemical composition between the particles being surveyed (Fuller et al., 1999).

New particle formation is not included in the current model since nucleation is not an important process in the highly polluted SJV (San Joaquin Valley) during a winter stagnation event. A source-oriented coagulation calculation is performed immediately following the gas-particle 
exchange calculations (Ying et al., 2008a; Zhang and Ying, 2010). This algorithm allows for coagulation between particles from the same source or from different sources. The fastest coagulation rates occur between the smallest particles that have high Brownian diffusivity and the largest particles that provide a large target for collisions. The source-oriented algorithm transfers the mass of smaller particles involved in coagulation events to the larger particles, and reduces the number concentration of the smaller particles. The "sourceorigin" of the larger particles is preserved, at least approximately, since the mass added by coagulation events is generally small relative to the total mass in these size fractions.

\subsection{Advection, vertical mixing, and deposition}

Mass transport is performed within the dynamic core of the WRF model. The SOWC model can be used with any of the advection options within the (EM_CORE). The positive definite advection option (3rd order) was used in the current study (Tremback et al., 1987). The standard Runge-Kutta method is used to calculate the tendency of each scalar array variable, and then solve the corresponding ordinary differential equation in order to update the scalar value at the next time step.

The asymmetric convective model version 2 (ACM2) (Pleim, 2007) was added to the SOWC model to more realistically represent the effects of mixing caused by turbulent eddies of multiple sizes through a combination of non-local vertical mixing and eddy diffusion. ACM2 calculations are conducted for all gas-phase and PM species in vertical levels within the convective boundary layer before the calculation of vertical mixing and dry deposition. In levels where ACM2 is active, the effects of non-local vertical diffusivity and local eddy diffusivity are calculated for each layer. ACM2 slightly increases the ozone transported to surface level from the upper atmosphere during winter stagnation events, which leads to improved performance for ozone and nitrate concentration predictions.

The Yonsei University planetary boundary layer (PBL) scheme (Hong et al., 2006) was used in the current application of the SOWC model. Dry deposition of gas species follows the existing Wesely module (Wesely, 1989), while dry deposition of particulate matter uses a modified version of the scheme in the UCD/CIT model that also accounts for settling rates of particles (Kleeman, 2001). There was no precipitation during the CRPAQS winter intensive period, and so calculations for wet deposition of particles and gases were not active. Future implementations of the SOWC model will use existing wet deposition algorithms in WRF or adopt the treatment used in offline source-oriented air quality models (Mahmud et al., 2010).

\subsection{Longwave and shortwave physics/aerosol- radiation feedback}

The SOWC model uses the shortwave radiation modules developed by the Goddard Space Flight Center (GSFC) (Chou and Suarez, 1994). The current study introduced a comparable GSFC longwave radiation module to the SOWC model framework (Chou and Suarez, 1999; Chou et al., 2001; S. H. Chen et al., 2010). The standard WRF/Chem code before the latest version (3.5) used a predefined concentration profile of internally mixed pollutants for all aerosol optics calculations. A new subroutine was implemented within the SOWC model to calculate layer-averaged optical properties of the size and source resolved aerosols. The refractive index for each particle size and source within each layer is calculated using the volume averaging method described by Stelson (1990) applied with a core and shell model for each particle as described by Toon and Ackerman (1981). Elemental carbon and metals are assumed to reside in the particle core while semivolatile materials and water are assumed to reside in the particle shell. A Mie routine is employed to calculate the optical properties for each particle, which are combined into the grid-cell average values of single scattering albedo, asymmetry parameter, and optical thickness. These three optical parameters are then used as inputs with the standard radiation transfer code that is part of the standard WRF model. This treatment is similar to the methods employed in the standard WRF/Chem model, but the SOWC model uses moving particle size bins that change diameter based on the condensation/evaporation of secondary components. The SOWC model therefore recalculates the index of refraction for each source-oriented particle and performs a full Mie calculation at every time step of the radiation transfer algorithm rather than using a fast approximation to this calculation as is done in the standard WRF/Chem model.

\section{Model application}

The San Joaquin Valley in California experiences some of the worst wintertime particulate air pollution in the United States (Ostro et al., 2006; Ostro and Chestnut, 1998; Woodruff et al., 2006) due to its unique mountain-valley topography and frequent stagnation events. The CRPAQS was a field campaign starting in December 1999 and ending in January 2001 (Chow et al., 2006). CRPAQS was designed to study elevated particulate matter (PM) concentrations in the SJV. During this campaign, concentrations of gaseous $\mathrm{CO}$, $\mathrm{NO}_{\mathrm{x}}$, and $\mathrm{O}_{3}$ were measured continuously throughout the valley. In addition, four different PM sampling events lasting 3-4 days each were conducted during the winter months. These intensive operation periods (IOPs) (14 December 2000 to 7 January 2001) collected information on particulate composition and size distributions, which can be used to support detailed modeling. Sampling and modeling studies focusing 
Table 2. Mean fractional biases (MFB) of particle scattering coefficient predicted by external run and internal run at 6 observation sites within the $4 \mathrm{~km}$ domain. $\mathrm{MFB}=\frac{2}{N} \sum \frac{P_{i}-O_{i}}{P_{i}+O_{i}}$.

\begin{tabular}{lccccccc}
\hline SITE & & ANGI & BAC & BTI & FSF & SDP & M14 \\
\hline $\begin{array}{l}\text { Particle } \\
\text { scattering } \\
\text { coefficient }\end{array}$ & External & -0.64 & -0.65 & -0.09 & -0.90 & -0.04 & -0.49 \\
\hline
\end{tabular}

Table 3. Statistics of meteorological parameters predicted by external run and internal run for all observation sites within the $4 \mathrm{~km}$ domain. RMSE and MAE are the root mean squared error and the mean absolute error, respectively. RMSE $=\sqrt{\frac{\sum\left(P_{i}-O_{i}\right)^{2}}{N}}$ and $\mathrm{MAE}=\frac{\sum\left(P_{i}-O_{i}\right)}{N}$.

\begin{tabular}{llccc}
\hline \multirow{4}{*}{ Temperature } & & Mean & RMSE & MAE \\
& Obs. & 8.05 & & \\
& External & 8.67 & 3.08 & 2.39 \\
& Internal & 8.67 & 3.09 & 2.39 \\
\hline \multirow{3}{*}{$\mathrm{RH}$} & Obs. & 69.94 & & \\
& External & 49.99 & 29.57 & 24.69 \\
& Internal & 50.13 & 29.52 & 24.63 \\
\hline \multirow{4}{*}{ wind } & Obs. & 1.03 & & \\
& External & 1.41 & 1.57 & 1.06 \\
& Internal & 1.41 & 1.57 & 1.06 \\
\hline \multirow{4}{*}{$V$ wind } & Obs. & 1.08 & & \\
& External & 1.51 & 1.81 & 1.19 \\
& Internal & 1.51 & 1.81 & 1.19 \\
\hline
\end{tabular}

on the CRPAQS episode have been well documented (Chow et al., 2006; Ying et al., 2008b, 2009).

The SOWC model was applied to simulate the air quality and meteorology in the SJV from 15 December 2000 to 6 January 2001. The modeling domain is a pair of nested grids at $12 \mathrm{~km} \times 12 \mathrm{~km}$ and $4 \mathrm{~km} \times 4 \mathrm{~km}$ resolution. The coarser outer domain has 125 grid cells in each direction, while the more spatially resolved $4 \mathrm{~km}$ domain has 100 grid cells in the west-east direction, and 106 grid cells in the south-north direction. Both domains have 31 vertical layers to the top of the modeling atmosphere at a pressure of $100 \mathrm{hPa}$. Figure 1 shows the outer and inner domains together with the surface terrain height. The outer domain encompasses the entire state of California. The inner domain extends from the San Francisco Bay Area eastward to the Sierra Nevada Mountains and then extends from the northern Sacramento Valley area southward to the edge of the Tehachapi Mountains.

The National Centers for Environmental Prediction (NCEP) Final (FNL) Operational Global Analysis dataset (http://rda.ucar.edu/datasets/ds083.2/) was downloaded and processed with WRF Preprocessing System (WPS) to pro- vide initial and boundary conditions. SOWC simulations were conducted without four dimensional data assimilation (FDDA) to minimize artificial forcing so that the effects of chemistry feedback on meteorology would be most apparent. A statistical analysis shows that model meteorological errors do not increase significantly with time, but the effects of a weak upper level disturbance after 24 December 2000 are overpredicted, which allows accumulated pollutant concentrations to escape from the SJV. This brief disruption undermines predicted pollutant concentrations during the latter half of the stagnation event. The analysis of pollutant concentrations in the following sections is focused on $24 \mathrm{De}$ cember 2000, 9 days into the simulation and the day before the weak upper level disturbance.

Since the purpose of this paper is to examine how the source-oriented representation of airborne particles influences feedback effects on meteorology, two sets of simulation were conducted using the same model. One run was configured as an internally mixed case, i.e., singular-source type so the source-oriented feature was concealed (internal case hereinafter). The internally mixed case combined emissions from all sources into a single source type and the number of source types tracked by the model was set to 1 . The second run was configured as a source-oriented externally mixed case, i.e., the true source-oriented run with multiplesource types (external case hereinafter). The results of the internal case and the external case are compared to see the differences caused by the source-oriented representation of particles.

\section{Results and discussion}

\subsection{Model performance evaluation}

Measurements from the CRPAQS study are used to evaluate the SOWC model performance. Observations from 6 sites, ANGI, BAC, BTI, FSF, SDP, and M14 are used for validation of particle scattering coefficients and pollutants species. The locations of these sites are shown in Fig. 1. Meteorological parameters are evaluated at 160 meteorological stations within the $4 \mathrm{~km}$ domain.

Table 2 summarizes the mean fractional bias (MFB) of hourly daytime particle scattering coefficient predicted by the external and internal cases. Generally, both cases underpredict measured particle scattering coefficients but the 
Table 4. MFB of PM and gas species predicted by the external run and internal run at 6 observation sites within the $4 \mathrm{~km}$ domain.

\begin{tabular}{llrrrrrr}
\hline \multirow{2}{*}{$\mathrm{SITE}$} & & ANGI & BAC & BTI & FSF & SDP & M14 \\
\hline \multirow{2}{*}{$\mathrm{PM}_{2.5}$} & External & 0.11 & -0.67 & -0.07 & 0.09 & -0.03 & - \\
& Internal & 0.25 & -0.51 & -0.08 & 0.17 & -0.04 & - \\
\hline \multirow{2}{*}{$\mathrm{N}(\mathrm{V})$} & External & -0.15 & -0.92 & 0.22 & -0.69 & -0.47 & -0.81 \\
& Internal & -0.11 & -0.76 & 0.37 & -0.56 & -0.4 & -0.62 \\
\hline \multirow{2}{*}{$\mathrm{NH}_{4}$} & External & -1.34 & -1.1 & -0.26 & -1.3 & -0.5 & -0.9 \\
& Internal & -1.38 & -0.94 & -0.08 & -1.26 & -0.5 & -0.76 \\
\hline \multirow{2}{*}{$\mathrm{S}(\mathrm{VI})$} & External & -0.38 & -0.8 & 0.32 & 0.03 & -0.04 & -0.36 \\
& Internal & -0.34 & -0.74 & 0.33 & 0.02 & -0.04 & -0.39 \\
\hline \multirow{2}{*}{$\mathrm{EC}$} & External & 0.33 & -0.9 & -0.04 & -0.31 & 0.32 & 0.33 \\
& Internal & 0.39 & -0.86 & -0.08 & -0.24 & 0.32 & 0.3 \\
\hline \multirow{2}{*}{$\mathrm{OC}$} & External & -0.21 & -1.01 & -0.39 & -0.2 & -0.26 & -0.54 \\
& Internal & -0.28 & -1 & -0.46 & -0.18 & -0.64 & -0.64 \\
\hline \multirow{2}{*}{$\mathrm{O}_{3}$} & External & -1.19 & -0.73 & -0.85 & -1.41 & -0.33 & -1 \\
& Internal & -1.19 & -0.72 & -0.84 & -1.41 & -0.31 & -1 \\
\hline \multirow{2}{*}{$\mathrm{CO}$} & External & - & -0.34 & -0.03 & -0.21 & -0.02 & -0.29 \\
& Internal & - & -0.3 & 0.03 & -0.15 & 0.02 & -0.24 \\
\hline \multirow{2}{*}{$\mathrm{NO}$} & External & -0.04 & -0.76 & -0.3 & -0.08 & -0.56 & -0.85 \\
& Internal & 0.03 & -0.74 & -0.25 & -0.04 & -0.53 & -0.81 \\
\hline \multirow{2}{*}{$\mathrm{NO}_{2}$} & External & 0.79 & -0.49 & -0.49 & -0.36 & -0.13 & -0.39 \\
& Internal & 0.82 & -0.45 & -0.45 & -0.32 & -0.1 & -0.36 \\
\hline & & & & & & &
\end{tabular}

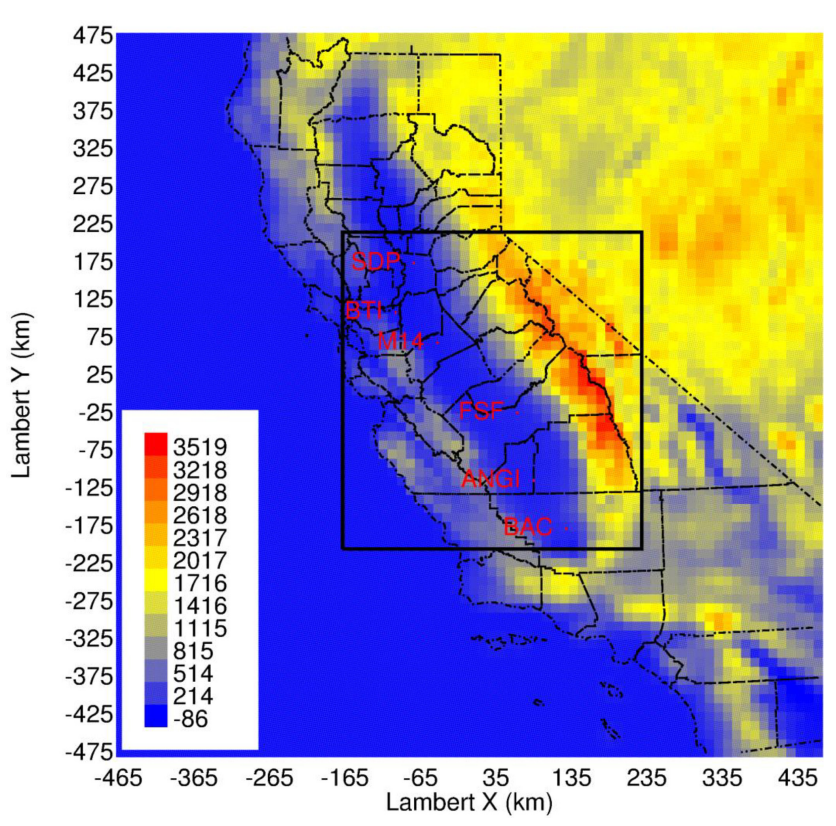

Fig. 1. Relative configuration of the nested WRF computation domains together with locations of 6 observation sites. The $4 \mathrm{~km}$ domain illustrated by the rectangle box covers the Central Valley. Color shows the terrain elevation in unit of $\mathrm{m}$. external case consistently produces lower MFB values at all sites. This indicates that the source-oriented representation of particles yields more accurate predictions of particle scattering coefficients than the internally mixed model. Table 3 presents the root mean squared errors (RMSE) and mean absolute errors (MAE) of meteorological parameters predicted by the external case and the internal cases using all available observations within the $4 \mathrm{~km}$ domain illustrated in Fig. 1. The RMSE and MAE of the internal and external runs for temperature and wind speed are similar, with differences observed in RH (relative humidity). In contrast, the differences in concentrations of PM and gas pollutants predicted using the internal vs. external cases are more pronounced. Table 4 shows MFB of PM and gas species predicted by the internal and external runs at 6 observation sites within the $4 \mathrm{~km}$ domain. The differences in secondary PM components (nitrate, ammonium, and sulfate) and total $\mathrm{PM}_{2.5}$ mass are larger than the differences in primary PM components (elemental carbon and organic carbon). The MFB of gas-phase $\mathrm{CO}, \mathrm{NO}$, and $\mathrm{NO}_{2}$ is qualitatively similar to the performance of primary PM elemental and organic carbon. Ozone concentrations predicted by the internal and source-oriented external models are very similar. Previous studies have demonstrated that local production of ozone is minimal during the cold winter months in the SJV (Brown et al., 2006; Hu et al., 2010; Pun et al., 2009). The majority of the ozone measured at the 
(a) Internal mixing
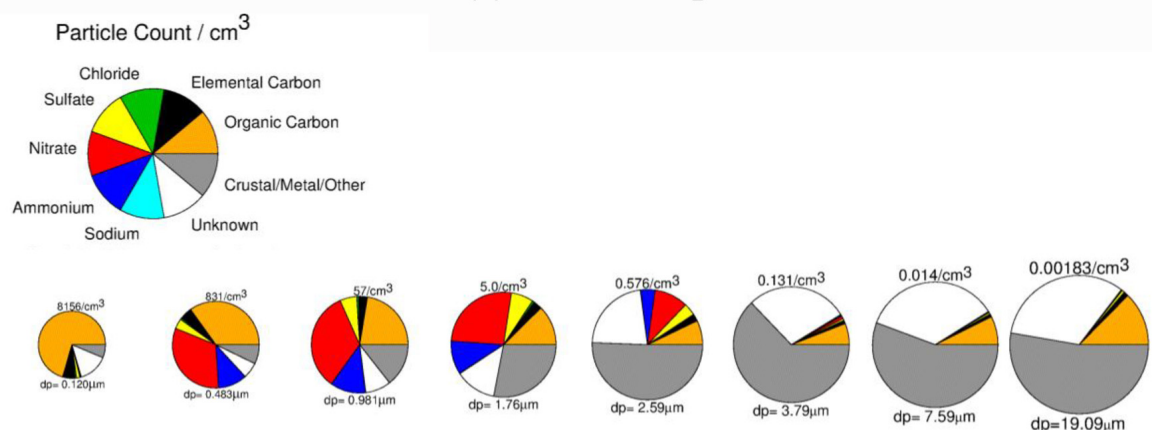

(b) External mixing

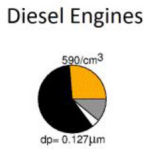

Wood Smoke
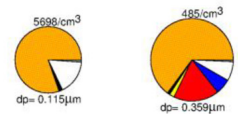

High Sulfur Fuel
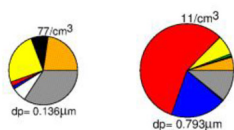

Food Cooking
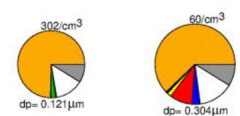

Other
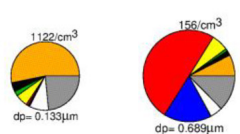
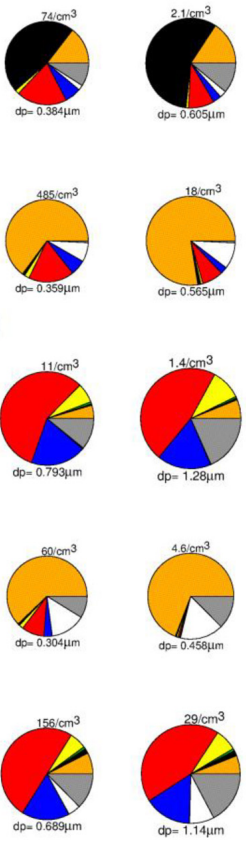
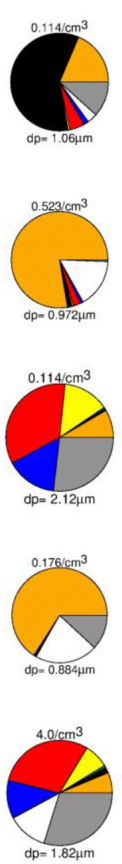
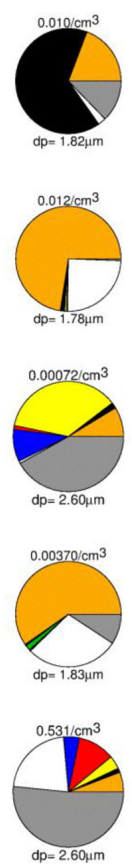
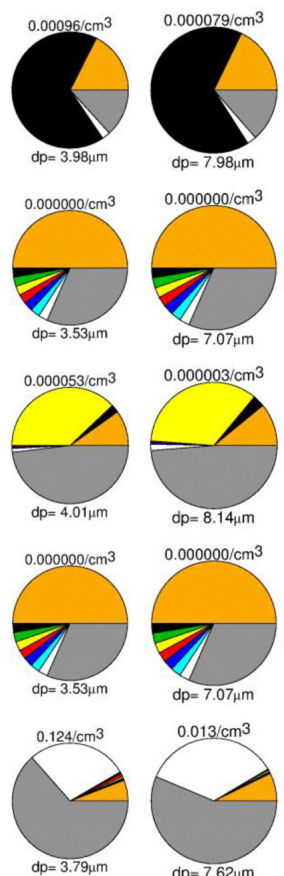
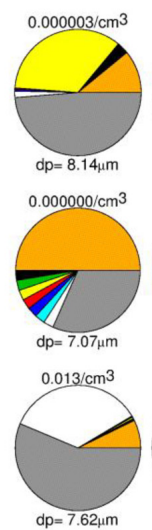
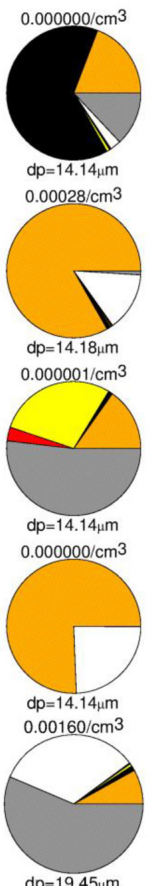

Fig. 2. (a) Internal and (b) external mixing state of the particles averaged from 12:00 to 13:00 LT (local time) on 24 December 2000 at surface level in Fresno, CA. Each of the pie charts illustrates the average chemical composition of a particle from a source (row) within a model size bin (column). The size of each pie chart is proportional to the log of the actual particle diameter.

surface is background ozone, transported into the study domain by the significant winds at higher elevations, that mixes to the surface when solar radiation warms the ground sufficiently to break the nocturnal surface inversion. Ozone destruction through titration by $\mathrm{NO}_{\mathrm{x}}$ in the chemical mechanism is the dominant path for nitrate formation in the SJV in the winter. Surface ozone concentrations decrease during the nighttime hours as a consequence of these chemical reactions.

\subsection{Model representation of aerosols}

Figure 2 shows the calculated black carbon mixing state of the particles in the external case and the internal case at the surface in Fresno, CA, at noon on 24 December 2000. In Fig. 2a, the internal mixing model predicts that black carbon is distributed evenly across all particles in the atmosphere. This assumption artificially coats black carbon with hygroscopic material that alters the optical properties of the particles. In Fig. 2b, the external case version of the model predicts that black carbon is concentrated in a minor number of total airborne particles. In these particles, black carbon accounts for more than $50 \%$ of the total mass with little hygroscopic material present.

Figure 3 presents the mass distribution of the internal mixture particle representation as a function of particle diameter at the surface level in Fresno, CA, at noon on 24 December 2000. Total particle mass has 3 modes between 0.2 and 


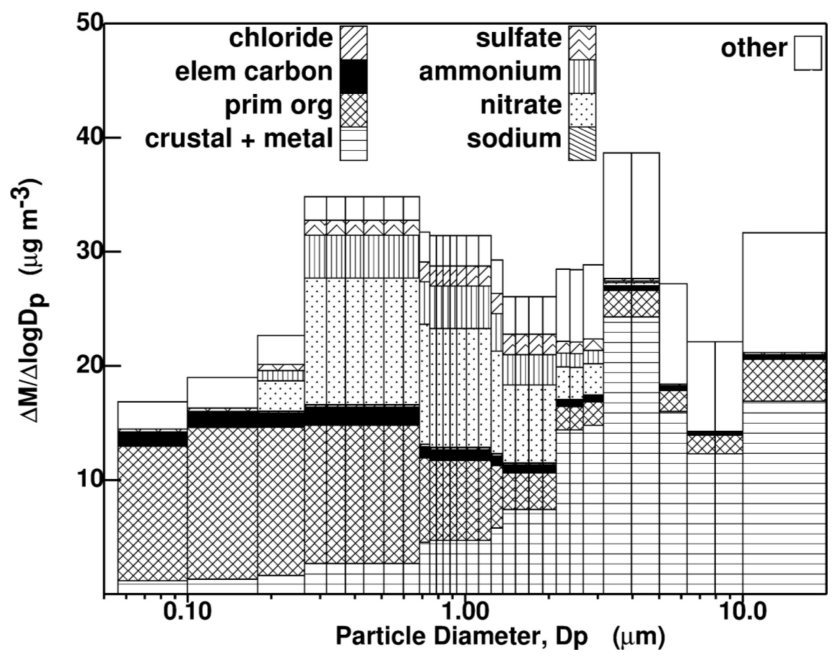

Fig. 3. Size distribution plot of the internal mixture particulate representation from 12:00 to 13:00 LT on 24 December 2000 in Fresno, California. The 8 moving model size bins are mapped to 32 standard size bins to facilitate a comparison with source-oriented results in Fig. 4f.

$0.5 \mu \mathrm{m}, 2$ and $4 \mu \mathrm{m}$, and $>10 \mu \mathrm{m}$ particle diameter. Elemental carbon accounts for only a small fraction of the mass in any size bin. Primary organic carbon dominates the mass at smaller particle diameters but plays a minor role at larger particle sizes. Nitrate is the most abundant secondary component for particles with diameters between 0.15 and $5 \mu \mathrm{m}$, with additional contributions from ammonium and sulfate.

In contrast to the internal case in Fig. 3, Fig. 4 shows the mass distribution as a function of size for particles represented as a source-oriented external mixture on 24 December 2000 (9 days into the simulation). Figure 4a shows that the majority of the elemental carbon mass is concentrated in particles emitted from diesel engines. A minor amount of secondary components such as nitrate, sulfate, and ammonium only partitioned onto diesel engine particles between 0.15 and $0.6 \mu \mathrm{m}$. The majority of the diesel engine particles do not appear to undergo significant aging through accumulation of secondary coatings. Wood smoke and food cooking particles are other major sources of primary PM that do not attract large amounts of secondary coating, similar to diesel engine emissions. The majority of the secondary coating of ammonium nitrate that forms on the atmospheric aerosol is attracted to particles with hygroscopic primary emissions, such as particles emitted from the combustion of fuel with high sulfur content, and particles included in the "other sources" category in the current study. Ammonium nitrate condenses onto particles emitted from these sources with a mass mode forming between 0.2 and $0.6 \mu \mathrm{m}$ that is much larger than the primary particle cores that act as the initial condensation site. Similar amounts of particulate nitrate are predicted using the source-oriented external mixture model and the internal mixture model, confirming the findings of previous studies that the primary particle mixing state does not strongly influence the saturation concentration product of gas-phase ammonia and nitric acid in the atmosphere (Kleeman and Cass, 2001; Ying et al., 2007, 2008a). However, the current study clearly demonstrates that the primary particle mixing state strongly affects the distribution of secondary ammonium nitrate on different particle cores, which in turn can strongly influence the optical properties of the atmosphere. The following sections quantify the feedback effects on meteorology and the resulting modification of pollutant concentrations based on the different treatments of particle mixing state.

\subsection{Meteorological feedback effects}

Figure 5 illustrates the aerosol extinction coefficients predicted by the external case and differences between external and internal cases. Figure 5a presents the $1 \mathrm{~h}$ averaged extinction coefficient predicted by external case at noon on 24 December 2000. The highest extinction coefficients are $0.83 \mathrm{~km}^{-1}$ in the SJV between Fresno and Bakersfield corresponding to the location with the greatest concentration of secondary ammonium nitrate. The difference between the external and internal mixture cases (Fig. 5b) shows that extinction coefficients calculated using the internal particle representation are higher than those predicted with the sourceoriented external representation in the SJV. The increased extinction is a consequence of artificially coating diesel engine particles with secondary ammonium nitrate and associated water. The average differences between the external case and the internal case in the SJV are $-0.012 \mathrm{~km}^{-1}(4.82 \%)$ with a maximum of $-0.22 \mathrm{~km}^{-1}$ near Bakersfield.

Downward clear-sky (aerosols but no clouds) shortwave radiation flux at the surface is affected by the source-oriented representation of aerosols. Figure 6a shows the downward shortwave flux predicted in the external case while Fig. $6 \mathrm{~b}$ shows the difference in the concentrations predicted by the internal and external cases. The external case predicted as much as $5 \mathrm{~W} \mathrm{~m}^{-2}$ higher shortwave flux in SJV relative to the internal case ( $\sim 1 \%$ increase). The average difference in the SJV is $0.93 \mathrm{~W} \mathrm{~m}^{-2}$. Changes in the predicted shortwave flux at the surface alter the PBL height and vertical mixing. Figure $6 \mathrm{c}$ shows the PBL height predicted by the SOWC model at noon, 24 December 2000, ranges from $\sim 400$ to $600 \mathrm{~m}$ in the SJV. Figure 6d illustrates that PBL heights predicted by the external case are $\sim 30-90 \mathrm{~m}$ greater than PBL heights predicted by the internal case.

Figure 7 (left column) shows the temperature at $2 \mathrm{~m}$ above the surface (T2), wind speed in the $x$ direction at $10 \mathrm{~m}$ above the surface $(U 10)$ and wind speed in the $y$ direction at $10 \mathrm{~m}$ above the surface $(V 10)$ predicted by the external case at noon on 24 December 2000. The right column of Fig. 7 illustrates the difference in the meteorological variables when airborne particles are represented as an internal mixture rather than a source-oriented external mixture. Predicted $T 2$ in the 
a) Diesel Engines

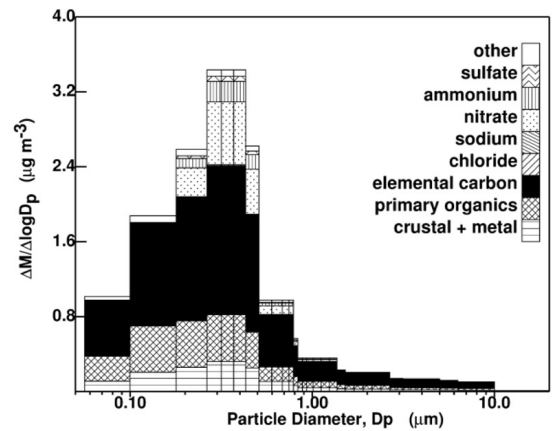

c) High Sulfur Fuel

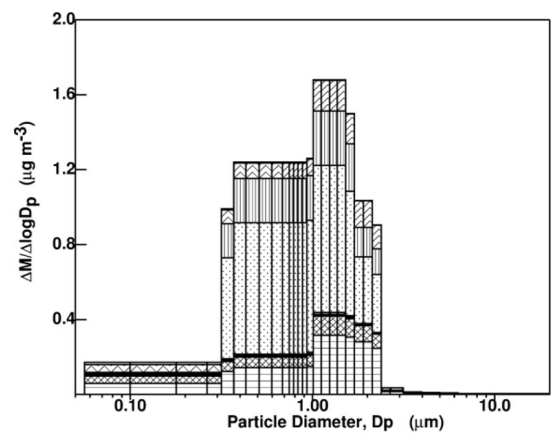

e) Other

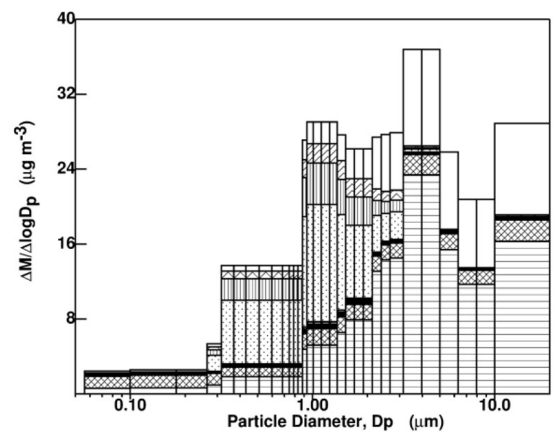

b) Wood Smoke

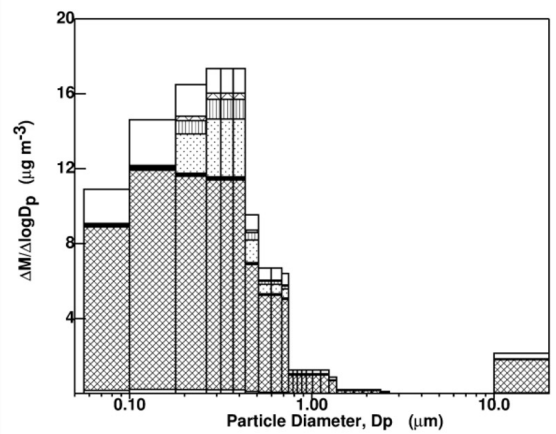

d) Food Cooking

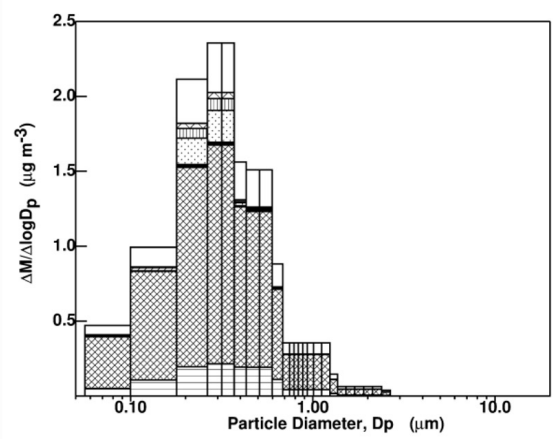

f) Total

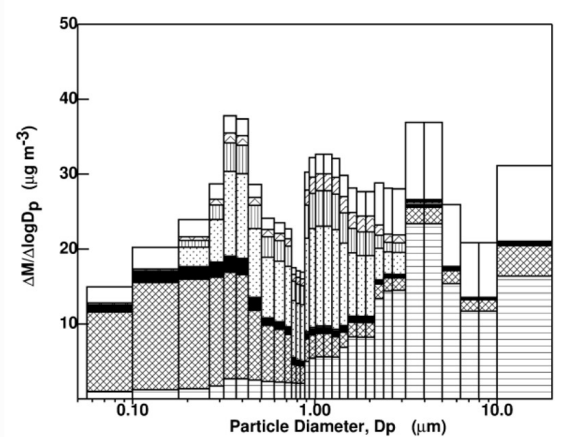

Fig. 4. Size distribution plot of the source-oriented external mixture particulate representation averaged from 12:00 to 13:00 LT on 24 December 2000 in Fresno, California. All five of the sources included in the simulations of the current study are presented in panels a-e along with the total size distribution in panel $\mathbf{f}$. The 8 moving model size bins from each source are mapped to 32 standard size bins to facilitate a comparison with internally mixed results in Fig. 3. Note that the maximum value of each panel is adjusted to best show the particle size distribution.

SJV is $\sim 280 \mathrm{~K}$ and the average difference between the internal and external cases is $\sim 0.087 \mathrm{~K}$ with the maximum of $\sim 2 \mathrm{~K}$. A coherent pattern of increased surface temperature in the external case is apparent in the SJV corresponding to the locations where aerosol extinction was reduced relative to the internal case. There are some points outside California where $T 2$ in the external case was lower than $T 2$ in the internal case. The locations over the ocean where this occurs are influenced by changes in sea spray as a result of changes to wind speed. The change in $T 2$ over the SJV does not fully characterize the magnitude of the redistribution of energy across the PBL. Wind speeds in the SJV predicted in the external and internal cases differ by averages of $0.030 \mathrm{~m} \mathrm{~s}^{-1}$ and $-0.013 \mathrm{~m} \mathrm{~s}^{-1}$ in the SJV as shown in Fig. $7 \mathrm{~d}$ and $\mathrm{f}$. The external case tends to predict slightly higher $U 10$ and lower 
(a) Extinction coefficient (External case) (12:00pm-13:00pm December 24, 2000)

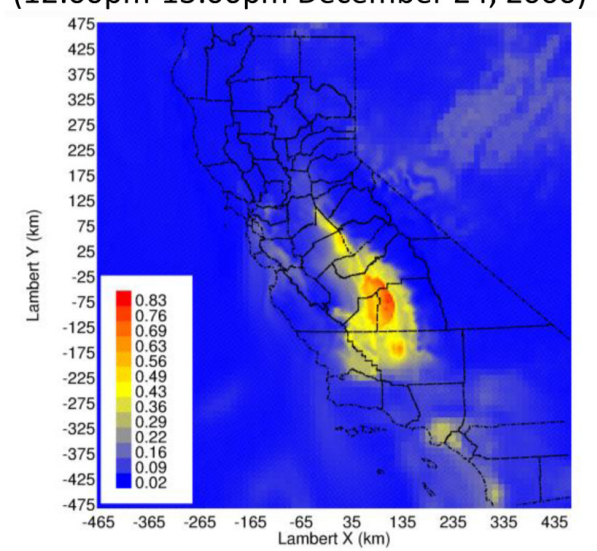

(b) Difference (External case - internal case)

(12:00pm-13:00pm December 24, 2000)

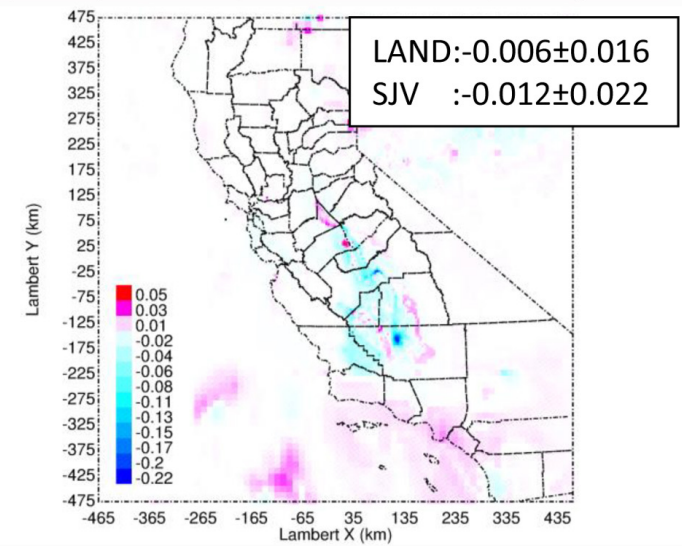

Fig. 5. Hourly extinction coefficient averaged from 12:00 to 13:00 LT on 24 December 2000 calculated by (a) the external case and (b) difference between external case and internal case in units of $\mathrm{km}^{-1}$. Note that the maximum value for each panel is adjusted to best illustrate the spatial patterns. Averaged differences over land and the SJV covered by the $4 \mathrm{~km}$ domain are shown in the text box.

(a) Downward short wave (External case)

(12:00pm-13:00pm December 24, 2000)

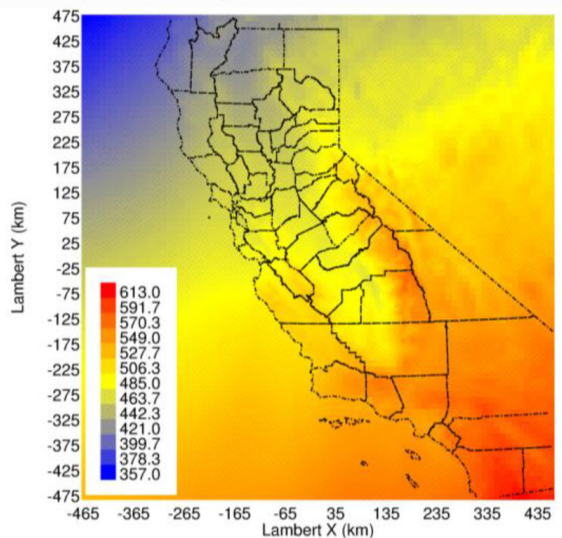

(c) PBL height (External case)

(12:00pm-13:00pm December 24, 2000)

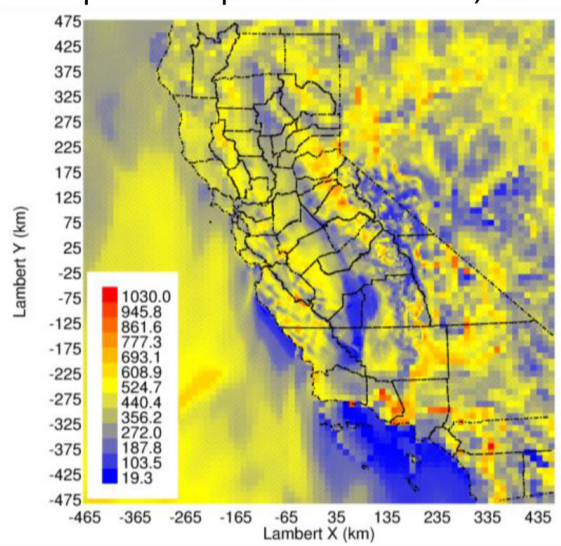

(b) Difference (External case - Internal case)

(12:00pm-13:00pm December 24, 2000)

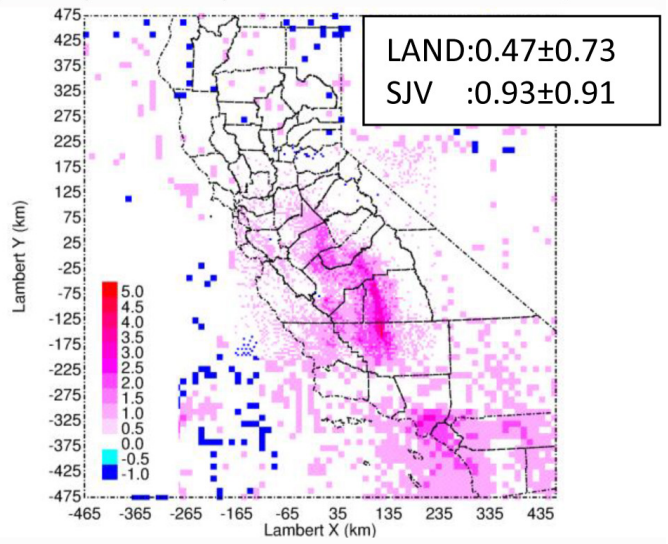

(d) Difference (External case - Internal case)

(12:00pm-13:00pm December 24, 2000)

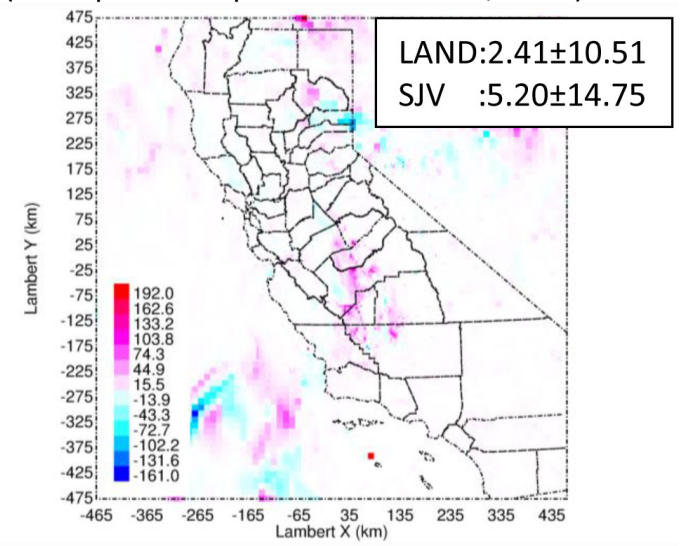

Fig. 6. Clear-sky downward radiation $\left(\mathrm{W} \mathrm{m}^{-2}\right)$ and PBL height $(\mathrm{m})$ calculated by the external case $(\mathbf{a}$ and $\mathbf{c})$ and difference between external case and internal case (b and d) from 12:00 to 13:00 LT on 24 December 2000. Note that the maximum value for each panel is adjusted to best illustrate the spatial patterns. Averaged differences over land and the SJV covered by the $4 \mathrm{~km}$ domain are shown in the text box. 
a) T2 (External case)

(12:00pm-13:00pm December 24, 2000)

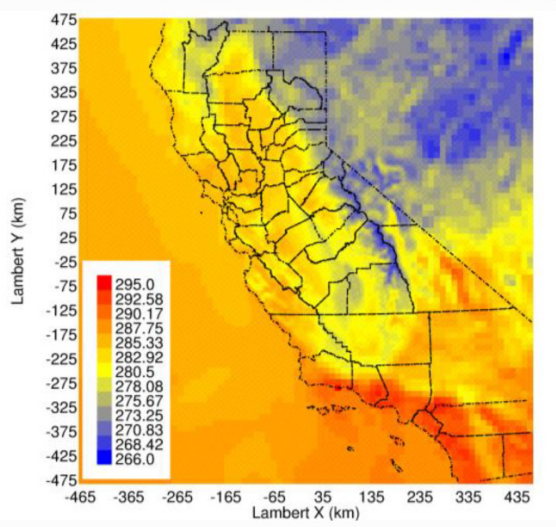

c) U10 (External case)

(12:00pm-13:00pm December 24, 2000)

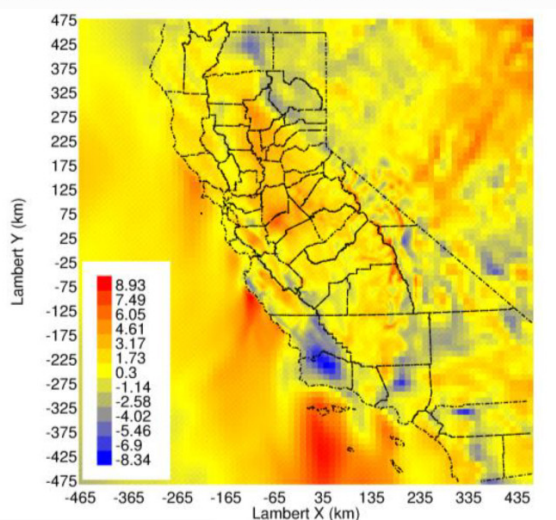

e) V10 (External case)

(12:00pm-13:00pm December 24, 2000)

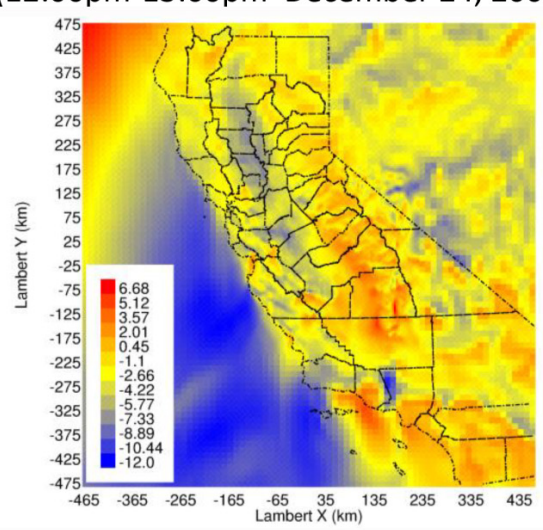

b) Difference (External case - Internal case)

(12:00pm-13:00pm December 24, 2000)

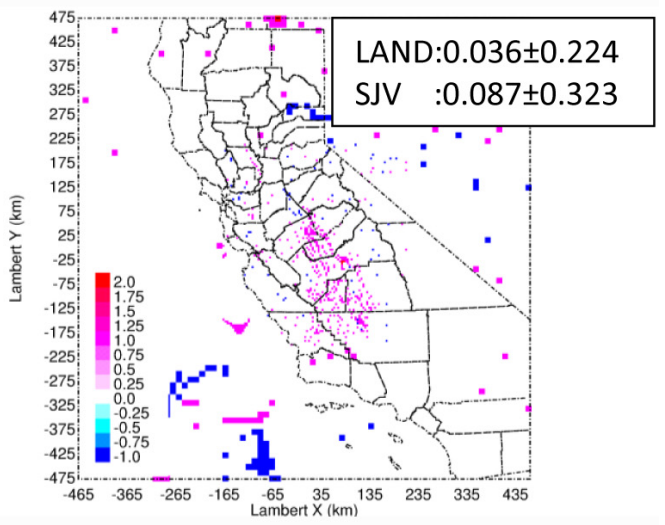

d) Difference (External case - Internal case)

(12:00pm-13:00pm December 24, 2000)

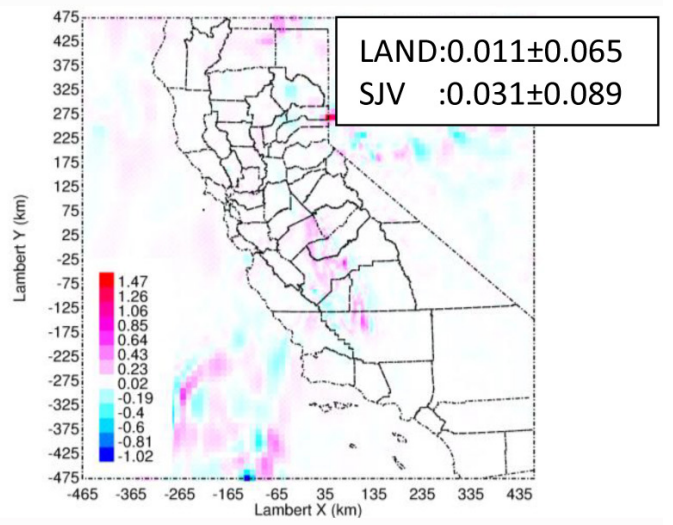

f) Difference (External case - Internal case)

(12:00pm-13:00pm December 24, 2000)

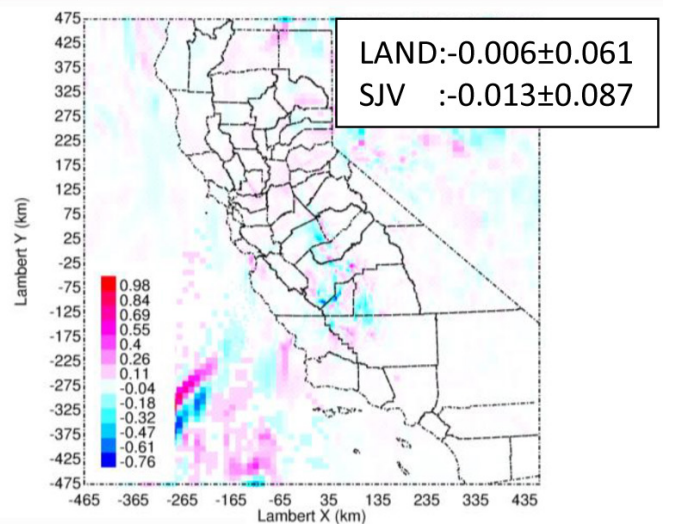

Fig. 7. $T 2(\mathrm{~K}), U 10\left(\mathrm{~ms}^{-1}\right)$ and $V 10\left(\mathrm{~ms}^{-1}\right)$ calculated by the external case (a, $\mathbf{c}$ and $\left.\mathbf{e}\right)$ and the differences between external case and internal case (b, d and f) from 12:00 to 13:00 LT on 24 December 2000. Note that the maximum value for each panel is adjusted to best illustrate the spatial patterns. Averaged differences over land and the SJV covered by the $4 \mathrm{~km}$ domain are shown in the text box.

$V 10$ in the SJV, with implications for dilution and pollutant concentrations.

Although the difference in downward shortwave flux appears to be minor, the effects on vertical mixing, atmospheric temperature structure, and wind speed are substantial. The magnification of differences in meteorological parameters affecting pollutant concentrations are expected to have large feedback effects on the predicted pollutant concentrations, as we will show in the next section. 
a) Diesel Engines

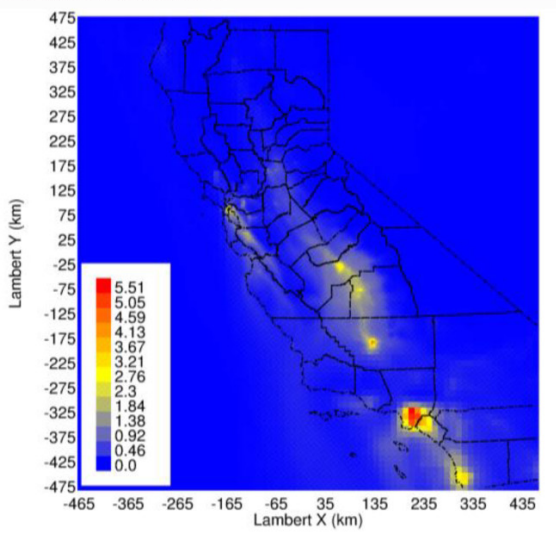

c) High Sulfur Fuel

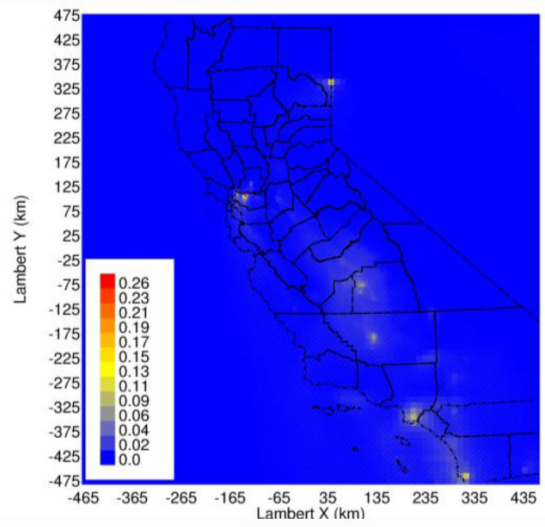

e) Other

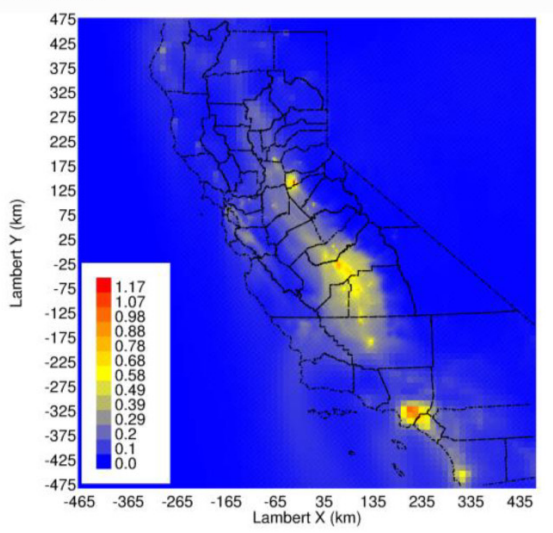

b) Wood Smoke

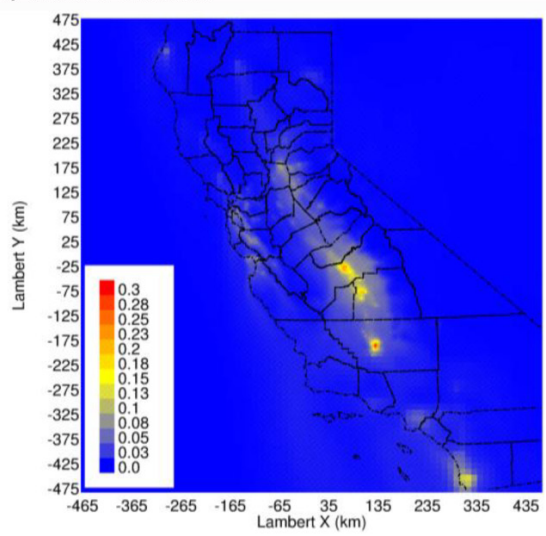

d) Food Cooking

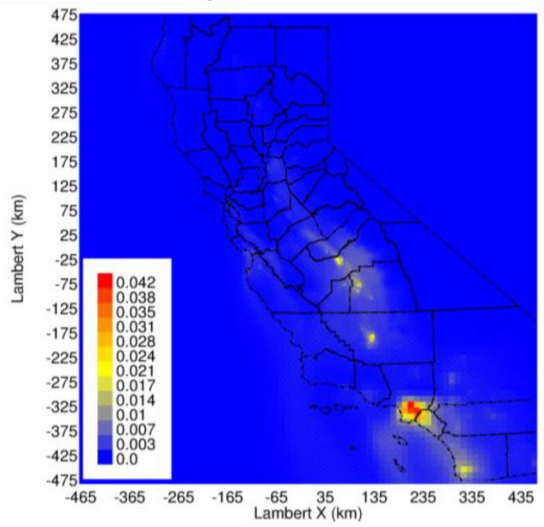

f) Difference (External case - Internal case)

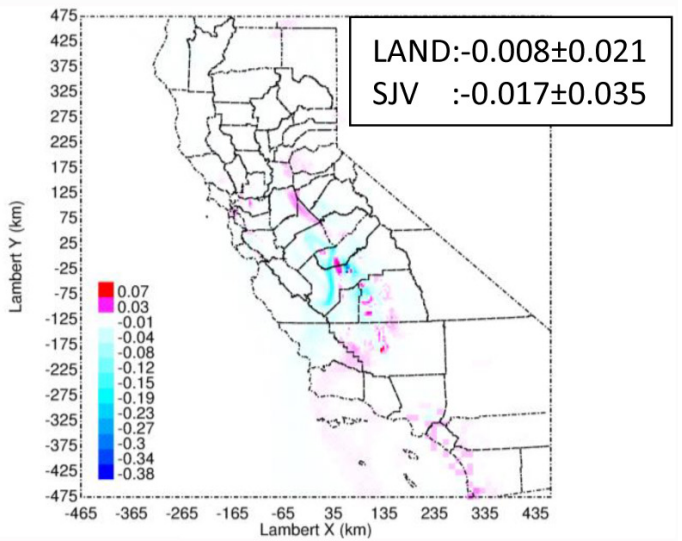

Fig. 8. $24 \mathrm{~h}$ averaged elemental carbon concentrations associated with primary particles emitted from different sources predicted by the external case (a-e) on 24 December 2000, and difference between external case and internal case (f). Units are $\mu \mathrm{g} \mathrm{m}^{-3}$. Note that the maximum value for each panel is adjusted to best illustrate the spatial patterns. Averaged differences over land and the SJV covered by the $4 \mathrm{~km}$ domain are shown in the text box.

\subsection{Differences in PM concentrations}

The source-oriented external mixture representation for airborne particles used in this study has a more realistic representation of particle optical properties and it can also mechanistically determine the primary particle cores that attract large amounts of secondary particulate matter over the entire model domain. Figures 8-10 illustrate the source-origin of the primary particle cores that are associated with elemental carbon, nitrate and total $\mathrm{PM}_{2.5}$. Since elemental carbon is a primary PM component, Fig. 8 illustrates a source apportionment plot. The nitrate and $\mathrm{PM}_{2.5}$ total mass illustrated 
a) Diesel Engines

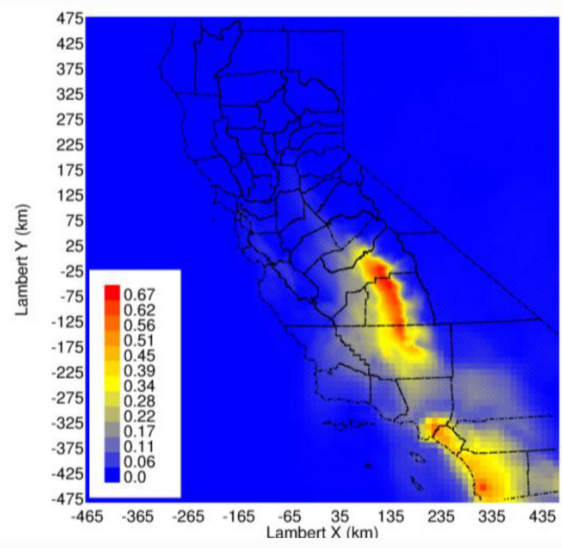

c) High Sulfur Fuel

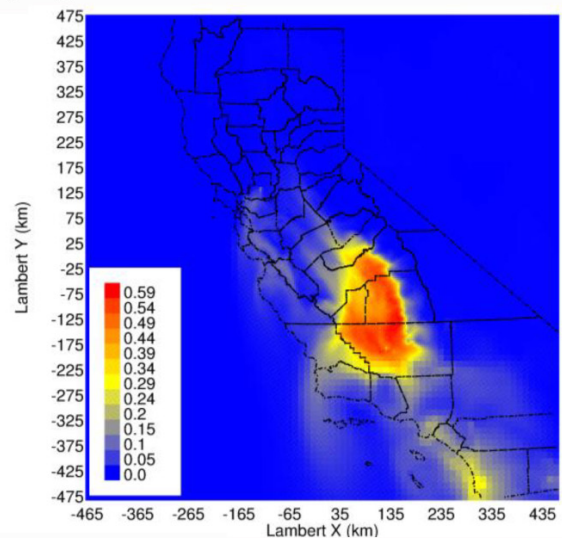

e) Other

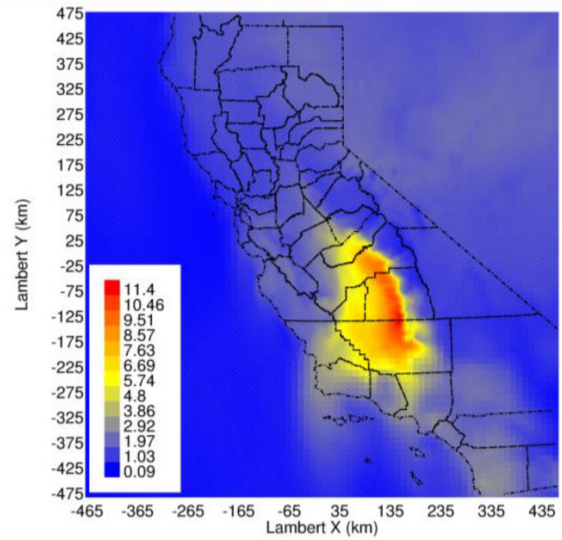

b) Wood Smoke

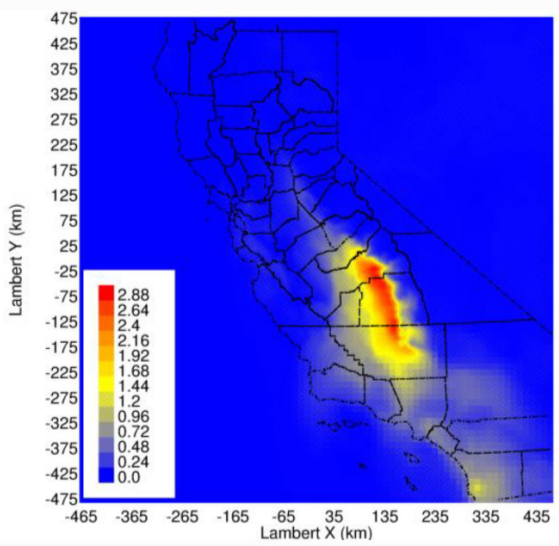

d) Food Cooking

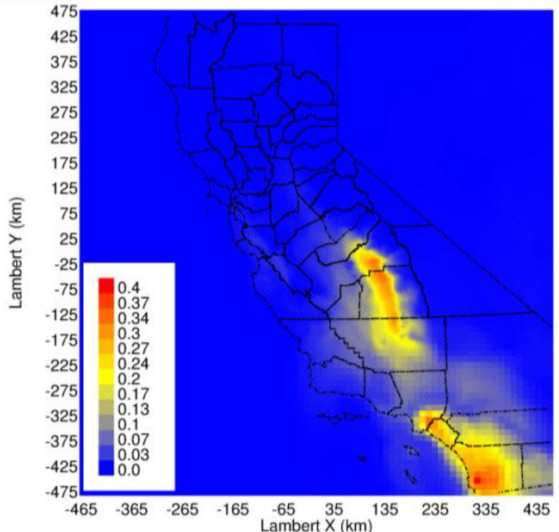

f) Difference (External - Internal)

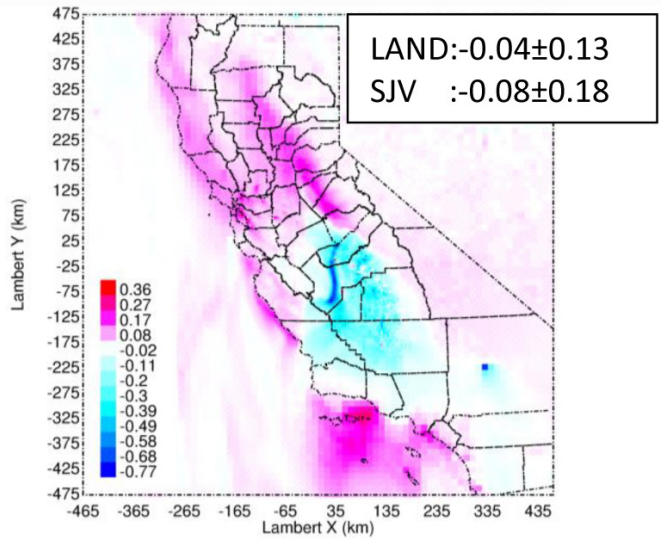

Fig. 9. $24 \mathrm{~h}$ averaged nitrate concentrations associated with primary particles emitted from different sources predicted by the external case (a-e) on 24 December 2000 and difference between external case and internal case (f). Units are $\mu \mathrm{g} \mathrm{m}^{-3}$. Note that the maximum value for each panel is adjusted to best illustrate the spatial patterns. Averaged differences over land and the SJV covered by the $4 \mathrm{~km}$ domain are shown in the text box.

in Figs. 9 and 10 may have originated as gas-phase emissions from other sources, and so these results should not be interpreted as a regional source apportionment map. Readers are referred to the results of previous studies that performed source apportionment for all primary and secondary
PM components for this information (Ying et al., 2008a, b, 2009).

Figure 8 shows the predicted $24 \mathrm{~h}$ averaged $\mathrm{PM}_{2.5}$ elemental carbon concentrations on 24 December 2000. Diesel engines dominate the total elemental carbon concentrations as shown in Fig. 8a. central Los Angeles (LA) has the 
a) Diesel Engines

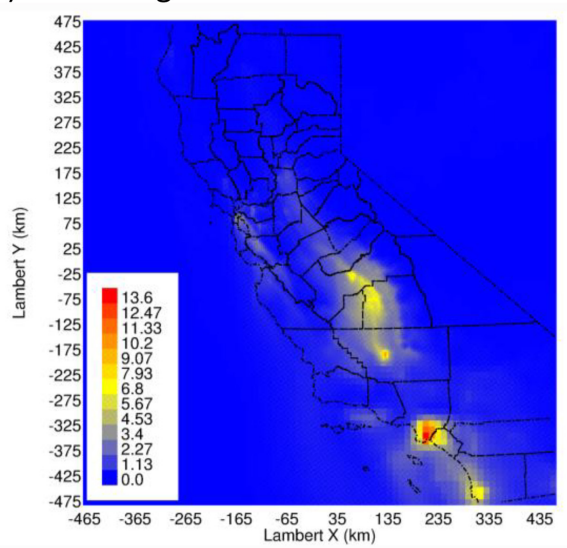

c) High Sulfur Fuel

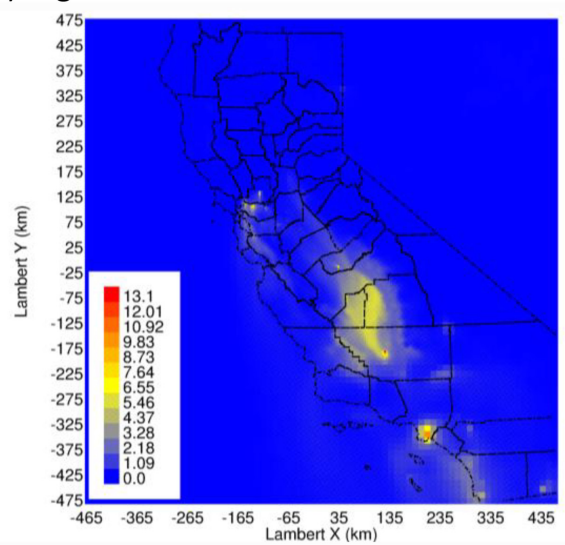

e) Other

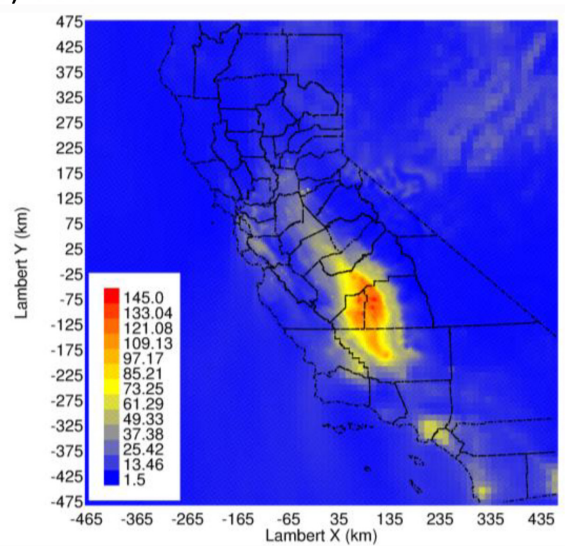

b) Wood Smoke

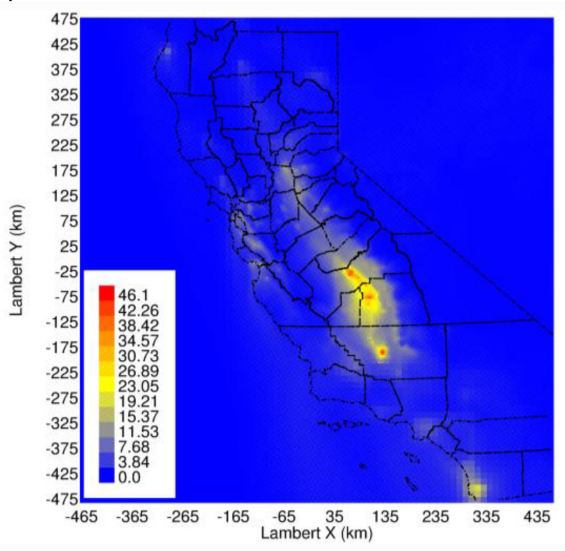

d) Food Cooking

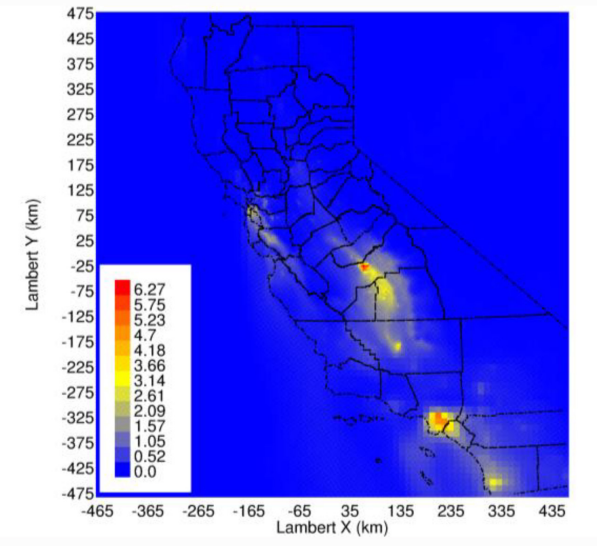

f) Difference (External - Internal)

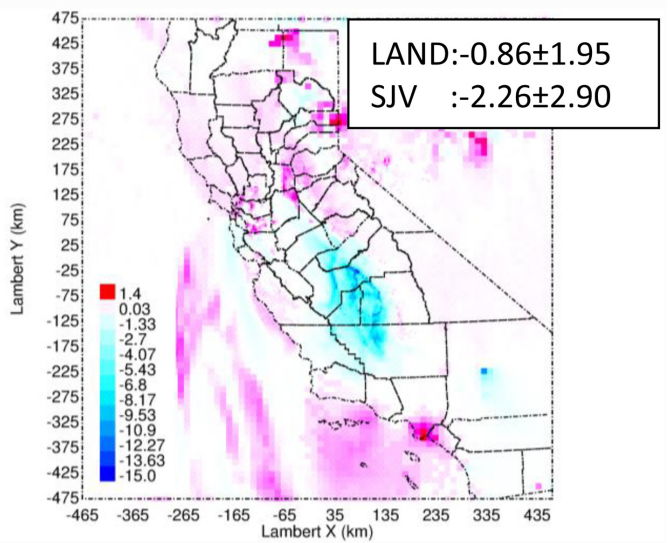

Fig. 10. $24 \mathrm{~h}$ averaged $\mathrm{PM}_{2.5}$ concentrations associated with primary particles emitted from different sources predicted by the external case (a-e) on 24 December 2000 and difference between external case and internal case (f). Units are $\mu \mathrm{g} \mathrm{m}^{-3}$. Note that the maximum value for each panel is adjusted to best illustrate the spatial patterns. Averaged differences over land and the SJV covered by the $4 \mathrm{~km}$ domain are shown in the text box.

highest elemental carbon concentration with maximum of $5.51 \mu \mathrm{g} \mathrm{m}^{-3}$. Elemental carbon concentrations from diesel engines within the SJV are $\sim 2-3 \mu \mathrm{g} \mathrm{m}^{-3}$ with a maximum at Bakersfield. Wood smoke contributes $\sim 0.2 \mu \mathrm{g} \mathrm{m}^{-3}$ of elemental carbon in the SJV, while high-sulfur fuel combustion and food cooking are not significant contributors.
Sources not resolved in the source-oriented external mixture contribute $\sim 1 \mu \mathrm{g} \mathrm{m}^{-3}$ to elemental carbon concentrations throughout the SJV and central LA areas. Figure $8 \mathrm{f}$ shows the difference in total $\mathrm{PM}_{2.5}$ elemental carbon predicted by external and internal cases. No coherent pattern can be observed in the concentration difference fields, with 
some localized cells experiencing a $0.07 \mu \mathrm{g} \mathrm{m}^{-3}$ increase in elemental carbon concentrations and some cells experiencing a $0.2 \mu \mathrm{g} \mathrm{m}^{-3}$ decrease with an averaged differences of $-0.017 \mu \mathrm{g} \mathrm{m}^{-3}$. These changes in predicted concentrations of elemental carbon concentrations are consequences of differences in meteorological conditions (PBL height and wind speed) and dry deposition resulting from changes in condensation or secondary components and coagulation between the external and internal cases. Elemental carbon concentrations peak during the nighttime hours during severe winter stagnation events in the SJV, making the $24 \mathrm{~h}$ average concentration less susceptible to changes in daytime mixing rates.

Figure 9 shows $24 \mathrm{~h}$ averaged $\mathrm{PM}_{2.5}$ nitrate concentrations associated with different primary particle cores on 24 December 2000. The spatial patterns for all particle cores are similar, with high concentrations in the SJV between Fresno and Bakersfield and slightly lower concentrations in southern California (see Fig. 9a-e). On a regional basis, particles emitted from diesel engines, food cooking and combustion of high-sulfur fuel have similar low amounts of particulate nitrate associated with them. The results shown in Fig. 4 illustrated that particles emitted from high-sulfur fuel combustion have an affinity for nitrate formation, but these point sources are sparse on a regional scale and so high-sulfur fuel combustion sources do not account for a significant amount of nitrate condensation in the SJV. Wood smoke is the most abundant explicit source of primary particles that act as a condensation site for nitrate, with a maximum associated nitrate concentration of $2.88 \mu \mathrm{g} \mathrm{m}^{-3}$ in the SJV. It is apparent from the results shown in Fig. 9 that fresh wood smoke particles emitted in urban centers like Fresno and Bakersfield do not account for a significant fraction of these condensation sites, since the highest nitrate concentrations occur to the east of these cities. Particles emitted from other sources are the dominant condensation sites for nitrate in the SJV, with maximum values as high as $11.4 \mu \mathrm{g} \mathrm{m}^{-3}$. The differences in total $\mathrm{PM}_{2.5}$ nitrate predicted between external and internal cases are shown in Fig. 9f. A coherent region of decreased nitrate concentrations is apparent between Fresno and Bakersfield in the SJV, with maximum concentration reductions as large as $0.77 \mu \mathrm{g} \mathrm{m}^{-3}$. A single grid cell in the $12 \mathrm{~km}$ domain over the city of Barstow also experiences a large reduction in predicted nitrate concentrations under the source-oriented external treatment of particles vs. the internal treatment. It is noteworthy that nitrate concentrations increased in northern California and in coastal locations by up to $0.36 \mu \mathrm{g} \mathrm{m}^{-3}$. These differences reflect the redistribution of solar energy, changes of vertical mixing and other meteorological conditions in the atmosphere and the subsequent feedback effects on particle concentrations.

Other primary and secondary PM components in the simulation exhibit similar behavior to either elemental carbon (primary) or nitrate (secondary) and thus are not shown. Figure 10 sums up all PM components to show total $\mathrm{PM}_{2.5}$ mass on 24 December 2000. Contributions from primary and sec- ondary components associated with primary diesel engine particles (Fig. 10a) have a maximum $\mathrm{PM}_{2.5}$ concentration of $\sim 13.6 \mu \mathrm{g} \mathrm{m}^{-3}$. The highest PM concentrations from diesel engines are found in proximity to major transportation corridors. Total $\mathrm{PM}_{2.5}$ concentrations associated with primary particles emitted from wood combustion have a maximum concentration of $46.1 \mathrm{\mu g} \mathrm{m}^{-3}$ in the SJV between Fresno and Bakersfield, with much lower concentrations apparent in southern California. Primary particles emitted from combustion of fuel with high sulfur content also attract secondary PM components that add up to contribute significantly to total $\mathrm{PM}_{2.5}$ concentrations in central California as shown in Fig. 10c. Combustion of jet fuel by two air force bases in this region accounts for the majority of these primary particle cores. Total $\mathrm{PM}_{2.5}$ concentrations associated with primary particle cores emitted from food cooking have a maximum concentration of $6.27 \mu \mathrm{g} \mathrm{m}^{-3}$. Primary particle cores emitted from other un-resolved sources (Fig. 10e) account for the majority of total $\mathrm{PM}_{2.5}$ total mass because they attract large amounts of secondary ammonium nitrate condensation. Maximum $\mathrm{PM}_{2.5}$ concentrations associated with material on these primary particle cores reaches $145 \mu \mathrm{g} \mathrm{m}^{-3}$ in the SJV.

Figure 10f illustrates the difference in total $\mathrm{PM}_{2.5}$ concentrations predicted using the source-oriented external mixture representation and the internal mixture representation for particles. The $24 \mathrm{~h}$ averaged differences in total $\mathrm{PM}_{2.5}$ mass on 24 December 2000 ranges from -15.0 to $1.4 \mu \mathrm{g} \mathrm{m}^{-3}$ with an average of $-2.06 \mu \mathrm{g} \mathrm{m}^{-3}$ in the SJV. The largest coherent patterns of differences are reductions in $\mathrm{PM}_{2.5}$ concentrations of 3-7\% between Fresno and Bakersfield in the central SJV when the source-oriented external mixture representation is employed.

Generally, the source-oriented external mixed representation of the particles presents a more realistic mixing scenario for elemental carbon compared to internal mixed representations or external mixing representations based on arbitrary rules. The source-oriented external case predicts that hydrophobic diesel engine particles remain largely uncoated during the 9 day simulation, while the internal mixture model predicts significant accumulation of secondary nitrate and water on diesel engine particles. The source-oriented treatment yields more realistic optical properties that provide more accurate feedbacks to meteorological conditions and pollutant concentrations. Although the changes in meteorological parameters are relative small, the effects are magnified for secondary PM concentrations, yielding significant differences in $\mathrm{PM}_{2.5}$ total mass.

\section{Conclusions}

A source-oriented WRF model with chemistry (SOWC) was created to more realistically age airborne particles with different hygroscopic and light absorption properties rather than instantaneously combining these particles into an internal 
mixture. The SOWC model was used to simulate a threeweek winter stagnation pollution event in central California as an initial demonstration of its features. Source oriented calculations were performed for 8 particle size fractions ranging from 0.01 to $10 \mu \mathrm{m}$ particle diameter with a spatial resolution of $4 \mathrm{~km}$ and hourly time resolution. Primary particles emitted from diesel engines, wood smoke, high-sulfur combustion, food cooking, and other anthropogenic sources were tracked separately throughout the simulation as they aged in the atmosphere.

The source-oriented external mixture representation of particles and the internal mixture representation of particles with the WRF model yield different predictions for total particle mass when meteorological feedbacks are considered. The aerosol extinction coefficients, downward shortwave radiation flux, PBL height, surface temperature, and wind fields all respond to the altered optical properties of the atmosphere resulting from the source-oriented external mixture representation of particles. This in turn affects the predicted concentrations of primary and secondary particulate matter. All of these results stem from the mixing state of black carbon in particles within the simulation. The sourceoriented model predicts that hydrophobic diesel engine particles remain largely uncoated during the simulation, while the internal mixture model predicts significant accumulation of secondary nitrate and water on diesel engine particles.

The SOWC model calculation in this study is arguably the most realistic simulation of primary particle aging over a regional scale with meteorological feedbacks enabled since it tracks particle mixing states realistically from the emissions source through the atmospheric aging calculation. The SOWC model is being used in our group for a high resolution application in the Port of Oakland (Joe et al., 2014) and a fog event and energy budgets in the SJV (Lee et al., 2013). The SOWC model is part of the open source WRF model and should enable useful future studies of interactions between air pollution, weather and climate for other scientists. Future work should focus on including warm and cold cloud processes in the model so that climate-relevant questions can be addressed.

\section{Supplementary material related to this article is available online at http://www.atmos-chem-phys.net/14/ 485/2014/acp-14-485-2014-supplement.pdf.}

Acknowledgements. This study was funded by the United States Environmental Protection Agency under grant no. R833372. Although the research described in the article has been funded by the United States Environmental Protection Agency it has not been subject to the Agency's required peer and policy review and therefore does not necessarily reflect the reviews of the Agency and no official endorsement should be inferred.

Edited by: N. Riemer

\section{References}

Ackermann, I. J., Hass, H., Memmesheimer, M., Ebel, A., Binkowski, F. S., and Shankar, U.: Modal aerosol dynamics model for Europe: development and first applications, Atmos. Environ., 32, 2981-2999, 1998.

Beaver, M. R., Freedman, M. A., Hasenkopf, C. A., and Tolbert, M. A.: Cooling enhancement of aerosol particles due to surfactant precipitation, J. Phys. Chem. A, 114, 7070-7076, 2010.

Borge, R., Alexandrov, V., José del Vas, J., Lumbreras, J., and Rodríguez, E.: A comprehensive sensitivity analysis of the WRF model for air quality applications over the Iberian Peninsula, Atmos. Environ., 42, 8560-8574, 2008.

Brown, S. G., Hyslop, N. P., Roberts, P. T., McCarthy, M. C., and Lurmann, F. W.: Wintertime vertical variations in particulate matter (PM) and precursor concentrations in the San Joaquin Valley during the California Regional Coarse PM/Fine PM Air Quality Study, J. Air Waste Manage., 56, 1267-1277, 2006.

Carter, W. P. L.: A detailed mechanism for the gas-phase atmospheric reactions of organic compounds, Atmos. Environ. AGen., 24, 481-518, 1990.

Chapman, E. G., Gustafson Jr., W. I., Easter, R. C., Barnard, J. C., Ghan, S. J., Pekour, M. S., and Fast, J. D.: Coupling aerosolcloud-radiative processes in the WRF-Chem model: Investigating the radiative impact of elevated point sources, Atmos. Chem. Phys., 9, 945-964, doi:10.5194/acp-9-945-2009, 2009.

Chen, J. J., Ying, Q., and Kleeman, M. J.: Source apportionment of visual impairment during the California regional $\mathrm{PM}_{10} / \mathrm{PM}_{2.5}$ air quality study, Atmos. Environ., 43, 6136-6144, 2009.

Chen, J. J., Ying, Q., and Kleeman, M. J.: Source apportionment of wintertime secondary organic aerosol during the California regional $\mathrm{PM}_{10} / \mathrm{PM}_{2.5}$ air quality study, Atmos. Environ., 44, 1331-1340, 2010.

Chen, S. H., Wang, S. H., and Waylonis, M.: Modification of Saharan air layer and environmental shear over the eastern Atlantic Ocean by dust-radiation effects, J. Geophys. Res., 115, D21202, doi:10.1029/2010JD014158, 2010.

Chou, M.-D. and Suarez, M. J.: An efficient thermal infrared radiation parameterization for use in general circulation models, NASA Tech. Memo., NASA, Laboratory for Atmospheres, NASA/Goddard Space Flight Center, Greenbelt, MD85 pp., 1994.

Chow, J. C., Chen, L. W. A., Watson, J. G., Lowenthal, D. H. Magliano, K. A., Turkiewicz, K., and Lehrman, D. E.: $\mathrm{PM}_{2.5}$ chemical composition and spatiotemporal variability during the California Regional $\mathrm{PM}_{10} / \mathrm{PM}_{2.5}$ Air Quality Study (CRPAQS), J. Geophys. Res.-Atmos., 111, D10S04, doi:10.1029/2005JD006457, 2006.

Fast, J. D., Gustafson, W. I., Easter, R. C., Zaveri, R. A., Barnard, J. C., Chapman, E. G., Grell, G. A., and Peckham, S. E.: Evolution of ozone, particulates, and aerosol direct radiative forcing in the vicinity of Houston using a fully coupled meteorology-chemistry-aerosol model, J. Geophys. Res.-Atmos., 111, D10S04, doi:10.1029/2005JD006721, 2006.

Fuller, K. A., Malm, W. C., and Kreidenweis, S. M.: Effects of mixing on extinction by carbonaceous particles, J. Geophys. Res.Atmos., 104, 15941-15954, 1999.

Ginoux, P., Chin, M., Tegen, I., Prospero, J. M., Holben, B., Dubovik, O., and Lin, S.-J.: Sources and distributions of dust 
aerosols simulated with the GOCART model, J. Geophys. Res.Atmos., 106, 20255-20273, 2001.

Grell, G. A., Peckham, S. E., Schmitz, R., McKeen, S. A., Frost, G., Skamarock, W. C., and Eder, B.: Fully coupled "online" chemistry within the WRF model, Atmos. Environ., 39, 6957-6975, 2005.

Held, T., Ying, Q., Kaduwela, A., and Kleeman, M.: Modeling particulate matter in the San Joaquin Valley with a source-oriented externally mixed three-dimensional photochemical grid model, Atmos. Environ., 38, 3689-3711, 2004.

Hong, S.-Y., Noh, Y., and Dudhia, J.: A new vertical diffusion package with an explicit treatment of entrainment processes, Mon. Weather Rev., 134, 2318-2341, 2006.

Hu, J., Ying, Q., Chen, J., Mahmud, A., Zhao, Z., Chen, S.-H., and Kleeman, M. J.: Particulate air quality model predictions using prognostic vs. diagnostic meteorology in central California, Atmos. Environ., 44, 215-226, 2010.

$\mathrm{Hu}$, J., Zhang, H., Chen, S., Wiedinmyer, C., Vandenberghe, F., Ying, Q., and Kleeman, M. J.: Predicting primary $\mathrm{PM}_{2.5}$ and $\mathrm{PM}_{0.1}$ trace composition for epidemiological studies in California, Environ. Sci. Technol., under review, 2013.

Huang, M., Carmichael, G. R., Adhikary, B., Spak, S. N., Kulkarni, S., Cheng, Y. F., Wei, C., Tang, Y., Parrish, D. D., Oltmans, S. J., D'Allura, A., Kaduwela, A., Cai, C., Weinheimer, A. J., Wong, M., Pierce, R. B., Al-Saadi, J. A., Streets, D. G., and Zhang, Q.: Impacts of transported background ozone on California air quality during the ARCTAS-CARB period - a multi-scale modeling study, Atmos. Chem. Phys., 10, 6947-6968, doi:10.5194/acp-10-6947-2010, 2010.

Jacobson, M. Z.: Studying the effects of aerosols on vertical photolysis rate coefficient and temperature profiles over an urban airshed, J. Geophys. Res.-Atmos., 103, 10593-10604, 1998.

Jacobson, M. Z.: Strong radiative heating due to the mixing state of black carbon in atmospheric aerosols, Nature, 409, 695-697, 2001.

Jacobson, M. Z.: A solution to the problem of nonequilibrium acid/base gas-particle transfer at long time step, Aerosol Sci. Tech., 39, 92-103, 2005.

Joe, D. K., Zhang, H., DeNero, S. P., Lee, H.-H., Chen, S.-H., McDonald, B. C., Harley, R. A., and Kleeman, M. J.: Implementation of a high-resolution Source-Oriented WRF/Chem model at the Port of Oakland, Atmos. Environ., 82, 351-363, 2014.

Kain, J. S.: The Kain-Fritsch convective parameterization: an update, J. Appl. Meteorol., 43, 170-181, 2004.

Kleeman, M. J. and Cass, G. R.: Source contributions to the size and composition distribution of urban particulate air pollution, Atmos. Environ., 32, 2803-2816, 1998.

Kleeman, M. J. and Cass, G. R.: A 3D Eulerian source-oriented model for an externally mixed aerosol, Environ. Sci. Technol., 35, 4834-4848, 2001.

Kleeman, M. J., Cass, G. R., and Eldering, A.: Modeling the airborne particle complex as a source-oriented external mixture, J. Geophys. Res., 102, 21355-21372, 1997.

Kleeman, M. J., Robert, M. A., Riddle, S. G., Fine, P. M., Hays, M. D., Schauer, J. J., and Hannigan, M. P.: Size distribution of trace organic species emitted from biomass combustion and meat charbroiling, Atmos. Environ., 42, 3059-3075, 2008.

Lee, H.-H., Chen, S.-H., Kleeman, M. J., Zhang, H., DeNero, S. P., and Joe, D. K.: Implementation of Warm-Cloud Processes in a
Source-Oriented WRF/Chem Model to Study Fog Formation and Energy Budgets in the Central Valley of California, J. Geophys. Res. Atmos., submitted, 2014.

Lesins, G., Chylek, P., and Lohmann, U.: A study of internal and external mixing scenarios and its effect on aerosol optical properties and direct radiative forcing, J. Geophys. Res., 107, 4094, doi:10.1029/2001JD000973, 2002.

Liao, H., Zhang, Y., Chen, W. T., Raes, F., and Seinfeld, J. H.: Effect of chemistry-aerosol-climate coupling on predictions of future climate and future levels of tropospheric ozone and aerosols, J. Geophys. Res.-Atmos., 114, D10306, doi:10.1029/2008JD010984, 2009.

Lin, Y.-L., Farley, R. D., and Orville, H. D.: Bulk parameterization of the snow field in a cloud model, J. Clim. Appl. Meteorol., 22, 1065-1092, 1983.

Mahmud, A., Hixson, M., Hu, J., Zhao, Z., Chen, S.-H., and Kleeman, M. J.: Climate impact on airborne particulate matter concentrations in California using seven year analysis periods, Atmos. Chem. Phys., 10, 11097-11114, doi:10.5194/acp10-11097-2010, 2010.

Mallet, M., Roger, J. C., Despiau, S., Putaud, J. P., and Dubovik, O.: A study of the mixing state of black carbon in urban zone, J. Geophys. Res.-Atmos., 109, D04202, doi:10.1029/2003JD003940, 2004.

Masson, V.: A physically-based scheme for the urban energy budget in atmospheric models, Bound.-Lay. Meteorol., 94, 357-397, 2000.

Matsui, H., Koike, M., Kondo, Y., Moteki, N., Fast, J. D., and Zaveri, R. A.: Development and validation of a black carbon mixing state resolved three-dimensional model: aging processes and radiative impact, J. Geophys. Res.-Atmos., 118, 2304-2326, 2013.

Mitchell, K. E., Lohmann, D., Houser, P. R., Wood, E. F., Schaake, J. C., Robock, A., Cosgrove, B. A., Sheffield, J., Duan, Q., Luo, L., Higgins, R. W., Pinker, R. T., Tarpley, J. D., Lettenmaier, D. P., Marshall, C. H., Entin, J. K., Pan, M., Shi, W., Koren, V., Meng, J., Ramsay, B. H., and Bailey, A. A.: The multiinstitution North American Land Data Assimilation System (NLDAS): utilizing multiple GCIP products and partners in a continental distributed hydrological modeling system, J. Geophys. Res.-Atmos., 109, D07S90, doi:10.1029/2003JD003823, 2004.

Mogo, S., Cachorro, V. E., Lopez, J. F., Montilla, E., Torres, B., Rodríguez, E., Bennouna, Y., and de Frutos, A. M.: In situ measurements of aerosol optical properties and number size distributions in a coastal region of Norway during the summer of 2008, Atmos. Chem. Phys., 12, 5841-5857, doi:10.5194/acp-12-58412012, 2012.

Ostro, B. and Chestnut, L.: Assessing the health benefits of reducing particulate matter air pollution in the United States, Environ. Res., 76, 94-106, 1998.

Ostro, B., Broadwin, R., Green, S., Feng, W. Y., and Lipsett, M.: Fine particulate air pollution and mortality in nine California counties: results from CALFINE, Environ. Health Persp., 114, 29-33, 2006.

Peckham, S., Grell, G. A., McKeen, S. A., Barth, M., Pfister, G., Wiedinmyer, C., Fast, J. D., Gustafson, W. I., Zaveri, R. A., Easter, R. C., Chapman, E., Hewson, M., Schmitz, R., Salzmann, M., and Freitas, S.: WRF/Chem Version 3.3 User's Guide, NOAA Technical Memo., Boulder, CO, US Dept. of Commerce, National Oceanic and Atmospheric Administration, Oceanic and 
Atmospheric Research Laboratories, Global Systems Division, 1-99, 2011.

Pleim, J. E.: A combined local and nonlocal closure model for the atmospheric boundary layer. Part I: Model description and testing, J. Appl. Meteorol. Clim., 46, 1383-1395, 2007.

Pun, B. K., Balmori, R. T. F., and Seigneur, C.: Modeling wintertime particulate matter formation in central California, Atmos. Environ., 43, 402-409, 2009.

Riemer, N., Vogel, H., and Vogel, B.: Soot aging time scales in polluted regions during day and night, Atmos. Chem. Phys., 4, 1885-1893, doi:10.5194/acp-4-1885-2004, 2004.

Riemer, N., West, M., Zaveri, R., and Easter, R.: Estimating black carbon aging time-scales with a particle-resolved aerosol model, Aerosol Sci., 41, 143-158, 2010.

Robert, M. A., Kleeman, M. J., and Jakober, C. A.: Size and composition distributions of particulate matter emissions: Part 2 Heavy-duty diesel vehicles, J. Air Waste Manage., 57, 14291438, 2007a.

Robert, M. A., VanBergen, S., Kleeman, M. J., and Jakober, C. A.: Size and composition distributions of particulate matter emissions: Part 1 - Light-duty gasoline vehicles, J. Air Waste Manage., 57, 1414-1428, 2007b.

Stelson, A. W.: Urban aerosol refractive index prediction by partial molar refraction approach, Environ. Sci. Technol., 24, 16761679, 1990.

Stokes, R. H. and Robinson, R. A.: Interactions in aqueous nonelectrolyte solutions. I. Solute-solvent equilibria, J. Phys. Chem.-US, 70, 2126-2131, 1966.

Toon, O. B. and Ackerman, T. P.: Algorithms for the calculation of scattering by stratified spheres, Appl. Optics, 20, 3657-3660, 1981.

Tremback, C. J., Powell, J., Cotton, W. R., and Pielke, R. A.: The forward-in-time upstream advection scheme: extension to higher orders, Mon. Weather Rev., 115, 540-555, 1987.

Vogel, B., Vogel, H., Bäumer, D., Bangert, M., Lundgren, K., Rinke, R., and Stanelle, T.: The comprehensive model system COSMO-ART - Radiative impact of aerosol on the state of the atmosphere on the regional scale, Atmos. Chem. Phys., 9, 86618680, doi:10.5194/acp-9-8661-2009, 2009.

Wesely, M. L.: Parameterization of surface resistances to gaseous dry deposition in regional-scale numerical models, Atmos. Environ., 23, 1293-1304, 1989.

Woodruff, T. J., Parker, J. D., and Schoendorf, K. C.: Fine particulate matter $\left(\mathrm{PM}_{2.5}\right)$ air pollution and selected causes of postneonatal infant mortality in California, Environ. Health Persp., 114, 786-790, 2006.

Ying, Q. and Kleeman, M. J.: Effects of aerosol UV extinction on the formation of ozone and secondary particulate matter, Atmos. Environ., 37, 5047-5068, 2003.

Ying, Q. and Kleeman, M. J.: Source contributions to the regional distribution of secondary particulate matter in California, Atmos. Environ., 40, 736-752, 2006.
Ying, Q. and Kleeman, M. J.: Regional contributions to airborne particulate matter in central California during a severe pollution episode, Atmos. Environ., 43, 1218-1228, 2009.

Ying, Q., Fraser, M. P., Griffin, R. J., Chen, J. J., and Kleeman, M. J.: Verification of a source-oriented externally mixed air quality model during a severe photochemical smog episode, Atmos. Environ., 41, 1521-1538, 2007.

Ying, Q., Lu, J., Allen, P., Livingstone, P., Kaduwela, A., and Kleeman, M. J.: Modeling air quality during the California Regional $\mathrm{PM}_{10} / \mathrm{PM}_{2.5}$ Air Quality Study (CRPAQS) using the UCD/CIT source-oriented air quality model - Part I. Base case model results, Atmos. Environ., 42, 8954-8966, 2008a.

Ying, Q., Lu, J., Kaduwela, A., and Kleeman, M.: Modeling air quality during the California Regional $\mathrm{PM}_{10} / \mathrm{PM}_{2.5}$ Air Quality Study (CPRAQS) using the UCD/CIT Source Oriented Air Quality Model - Part II. Regional source apportionment of primary airborne particulate matter, Atmos. Environ., 42, 89678978, 2008b.

Ying, Q., Lu, J., and Kleeman, M. J.: Modeling air quality during the California Regional $\mathrm{PM}_{10} / \mathrm{PM}_{2.5}$ Air Quality Study (CRPAQS) using the UCD/CIT sourceoriented air quality model - Part III. Regional source apportionment of secondary and total airborne particulate matter, Atmos. Environ., 43, 419-430, 2009.

Zaveri, R. A., Easter, R. C., Fast, J. D., and Peters, L. K.: Model for Simulating Aerosol Interactions and Chemistry (MOSAIC), J. Geophys. Res.-Atmos., 113, D13204, doi:10.1029/2007JD008782, 2008.

Zaveri, R. A., Barnard, J. C., Easter, R. C., Riemer, N., and West, M.: Particle-resolved simulation of aerosol size, composition, mixing state, and the associated optical and cloud condensation nuclei activation properties in an evolving urban plume, J. Geophys. Res.-Atmos., 115, D17210, doi:10.1029/2009JD013616, 2010.

Zhang, H. and Ying, Q.: Source apportionment of airborne particulate matter in Southeast Texas using a source-oriented 3D air quality model, Atmos. Environ., 44, 3547-3557, 2010.

Zhang, H. and Ying, Q.: Secondary organic aerosol formation and source apportionment in Southeast Texas, Atmos. Environ., 45, 3217-3227, 2011.

Zhang, H. and Ying, Q.: Secondary organic aerosol from polycyclic aromatic hydrocarbons in Southeast Texas, Atmos. Environ., 55, 279-287, 2012.

Zhang, H., Li, J., Ying, Q., Yu, J. Z., Wu, D., Cheng, Y., He, K., and Jiang, J.: Source apportionment of $\mathrm{PM}_{2.5}$ nitrate and sulfate in China using a source-oriented chemical transport model, Atmos. Environ., 62, 228-242, 2012.

Zhang, H., Li, J., Ying, Q., Guven, B. B., and Olaguer, E. P.: Source apportionment of formaldehyde during TexAQS 2006 using a source-oriented chemical transport model, J. Geophys. Res.-Atmos., 118, 1525-1535, 2013. 